\title{
Synthesis, Crystal Structure and ADME Prediction Studies of Novel Imidazopyrimidines as Antibacterial and Cytotoxic Agents
}

Heba T. Abdel-Mohsen*a, Amira Abood ${ }^{a}$, Keith J. Flanagan ${ }^{b}$, Alina Meindl $^{b}$, Mathias O. Senge ${ }^{b}$, Hoda I. El Diwani ${ }^{a}$

${ }^{a}$ Department of Chemistry of Natural and Microbial Products, Division of Pharmaceutical and Drug Industries Research, National Research Centre, Dokki, P.O. 12622, Cairo, Egypt

${ }^{b}$ Medicinal Chemistry, Trinity Translational Medicine Institute, Trinity Centre for Health Sciences, Trinity College Dublin, The University of Dublin, St. James's Hospital, Dublin 8, Ireland.

Corresponding author: Email address: hebabdelmohsen@gmail.com; ht.abdelmohsen@nrc.sci.eg

\begin{abstract}
In the present study a novel series of polyfunctionalized imidazopyrimidines 6a-u and 9a-d were efficiently constructed by a domino reaction between 2-imino-6-substituted-2,3dihydropyrimidin-4(1H)-ones 4a-d or 8a-c and 2-bromoacetophenones 5a-i under mild basic conditions. The synthesized series were screened for their antibacterial activity against Staphylococcus aureus and Bacillus subtilis as Gram positive (+) bacteria as well as against Gram negative (-) bacteria Escherichia coli, Klebsiella pneumonia, Pseudomonas aeruginosa, and Salmonella typhi. Most of the synthesized derivatives of imidazopyrimidines $\mathbf{6}$ and $\mathbf{9}$ showed remarkable selectively against Gram (-) bacteria over the Gram (+) ones. Compounds $6 \mathbf{c}, \mathbf{6 f}$ and 6g displayed potent and broad spectrum of antibacterial activity against all tested strains. Compounds $\mathbf{6 f}$ and $\mathbf{6 g}$ displayed promising inhibitory activity on GryB ATPase from E. coli with $\mathrm{IC}_{50}=1.14$ and $0.73 \mu \mathrm{M}$, respectively. Simultaneously, some of the synthesized imidazopyrimidine were screened for their antiproliferative activity against 60 cancer cell lines at a concentration of $10 \mu \mathrm{M}$. Compound 9d showed potent activity against most of the tested cell lines with mean growth inhibition of $37 \%$. ADME prediction study demonstrated that the synthesized hits have, in addition to their promising chemotherapeutic activity, acceptable pharmacokinetic properties and drug-likeness nature to be further developed.
\end{abstract}

Keywords: imidazopyrimidine; antibacterial activity; antiproliferative activity; ADME 


\section{Introduction}

Recently, the emergence of drug resistant infectious diseases has become one of the most concerning global health problems results in high rates of mortality due to treatment failure [1]. Over-prescription of the currently available antibiotics and low discovery of new antibiotics are the major factors that accelerate the evolution of drug resistant bacterial infections [2]. S. aureus, K. pneumoniae, P. aeruginosa, followed by Salmonella species are examples of multi-resistant bacteria for which new antibiotics are urgently required [3]. Therefore, new modes of targeting drug resistant bacteria are required. One such avenue is targeting the DNA gyrase of bacteria. DNA gyrase, a bacterial type II topoisomerase, is involved in controlling the topological state of DNA in bacteria [4]. Gryase enzyme consists of two catalytic subunits in a heterodimer $\left(A_{2} B_{2}\right)$. GyrA is involved in the break and reunion of the double stranded DNA and GyrB has the ATP binding site and is involved in the hydrolysis of ATP to provide sufficient energy for DNA supercoiling [4]. Hence, gyrase B is a well-established target for the development of potential novel antibacterial agents [5]. Over the last years, different chemical classes of gyrase B inhibitors that act on ATP binding site were identified [6,7]. Pyrrolopyrimidines (such as I) [8, 9], imidazo[1,2-a]pyridines (such as II) [10], benzimidazole ureas (such as III) [11], imidazopyrazinones (such as IV) [12], benzothiazoles (such as V) [13], indazoles (such as VI) [14], 4,5'-bithiazoles (such as VII) [15], and aminopyrimidines (such as VIII [16], are examples of reported ATP GyrB inhibitors (Figure. 1). Despite the achieved progress, many of the identified derivatives fail in the clinical trials because of unsatisfactory physicochemical and pharmacokinetic properties [17]. 
<smiles></smiles><smiles>NC1CCC(c2cc3c(cc2F)n2ccnc2c(=O)n3C2CC2)C1</smiles>

IV<smiles>CCNC(=O)Nc1ccc2nc(-c3cc(C(=O)O)no3)cn2n1</smiles>
II<smiles>O=C(O)C(=O)Nc1ccc2nc(NC(=O)c3cc(Br)c(Br)[nH]3)sc2c1</smiles>

V<smiles>CCNC(=O)Nc1nc2cc(OC)c(-c3cnc(OC)nc3)cc2[nH]1</smiles>

III<smiles>Cc1cc(=O)oc2cc(SCc3n[nH]c4cccc(OCc5ccc(C(C)(C)C)cc5)c34)ccc12</smiles><smiles>CCC(=O)Nc1nc(C)c(-c2csc(Nc3ccc(C(=O)O)cc3)n2)s1</smiles>

VII<smiles>O=C(O)/C=C/c1cccc(-c2cnc(Nc3ccc(F)c(Cl)c3)nc2-n2ccc(C(F)(F)F)n2)c1</smiles>

VIII

Figure 1. Examples of different classes of GyrB inhibitors I-VIII.

Also, resistance to chemotherapeutic agents is regarded as one of the major factors that reduce the efficacy of cancer therapy and leads to the classification of cancer as the second most common cause of death worldwide [18]. More specifically, pharmacokinetic resistance is responsible for clinical failure of a high percentage of new and currently present anticancer agents [19].

Considering these facts, there is a challenging requirement to design and synthesize new chemotherapeutic agents with favorable pharmacokinetic profiles to overcome the phenomena of 
numerous drug resistances. The research in this area needs to develop newer and safer derivatives of known drugs as well as to discover newer scaffolds that may have different modes of action.

In this regard, pyrimidines mimic the molecules in the biological systems and hence, regarded as important building blocks in the field of drug discovery and development [20-25]. Recently, AlTel and Al-Qawasmeh reported the synthesis of novel series of imidazopyrimidines, for example IX, of potent antibacterial activity [26]. Meanwhile, Kamal et al.[27] demonstrated the promising anticancer activity of some benzimidazole-imidazopyrimidine conjugates such as compound $\mathbf{X}$ against different cell lines [27]. On the basis of this background and as a continuation of our efforts in the synthesis of new chemotherapeutic agents [20, 21, 23, 24, 28, 29], the main aim of this study is to synthesize a novel series of polyfunctionalized imidazopyrimidines 6 and 9 (Figure 2) that could provide other chemotherapeutic opportunities in drug discovery. The synthesized compounds were evaluated for their antibacterial activity against some Gram $(+)$ and Gram (-) bacteria. The most promising candidates were further evaluated for their inhibitory activity on gyrase B ATPase. Concurrently, some of the synthesized compounds were selected by NCI to be screened for their in vitro cytotoxic activity. Besides, in silico ADME prediction study was carried out to predict pharmacokinetic parameters and the drug-likeness nature of the synthesized imidazopyrimidines. 


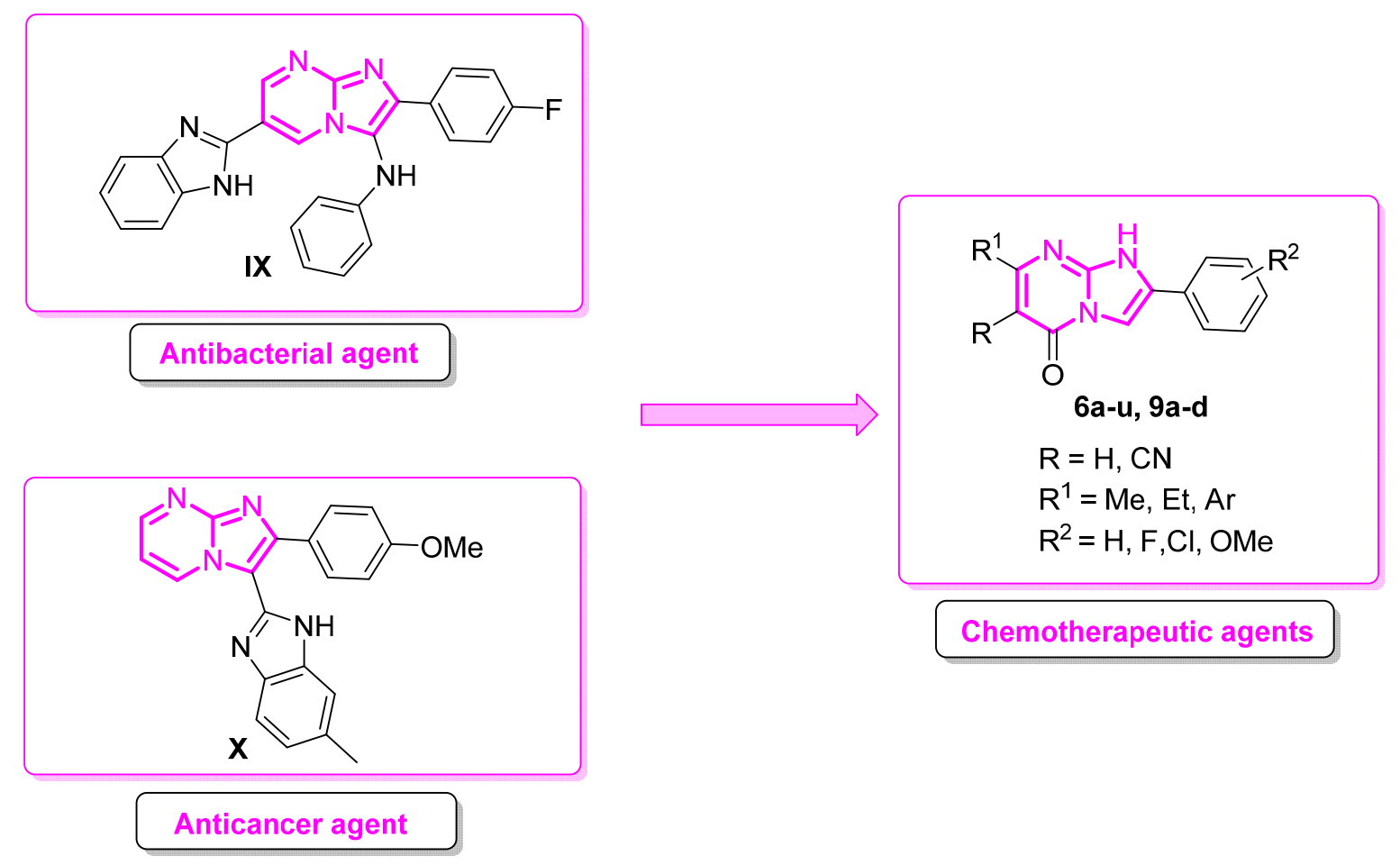

Figure 2. Rational for the design of the new imidazopyrimidines 6a-u and 9a-d.

\section{Results and discussion}

\subsection{Chemistry}

For the synthesis of the target compounds 6a-u, a series of 2-imino-4-oxo-6-(un)substitutedphenyl-1,2,3,4-tetrahydropyrimidine-5-carbonitriles 4a-d were first synthesized by one-pot reaction of guanidine hydrochloride (1), ethyl cyanoacetate (2), and aromatic aldehydes $\mathbf{3 a - d}$ in the presence of anhydrous $\mathrm{K}_{2} \mathrm{CO}_{3}$ to give the corresponding 2-imino-4-oxo-6-(un)substitutedphenyl-1,2,3,4-tetrahydropyrimidine-5-carbonitriles 4a-d [28]. Compounds 4a-d were subsequently reacted with different 2-bromoacetophenones 5a-i under basic conditions to give the corresponding cyclized products $\mathbf{6 a - u}$ in good yields under mild reaction conditions (Scheme $1)$. 


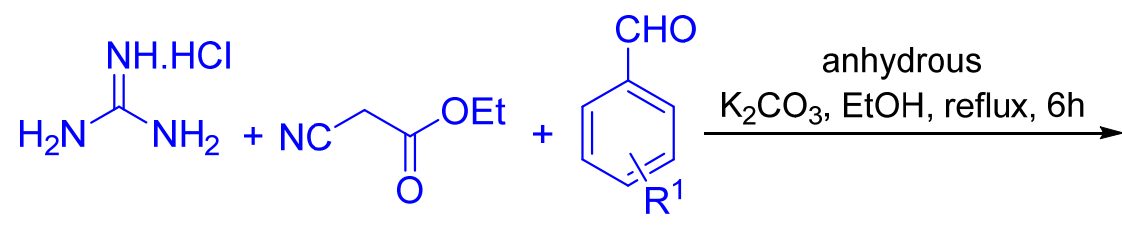

1 2 3<smiles>Cc1c(-c2cc#[R]cc2)[nH]c(=N)[nH]c1=O</smiles>

4a $\mathrm{R}^{1}=\mathrm{H}$ 4b R $\mathrm{R}^{1}=4-\mathrm{OMe}$ 4c $\mathrm{R}^{1}=2,5-\mathrm{OMe}$ 4d $\mathrm{R}^{1}=3,4,5-\mathrm{OMe}$

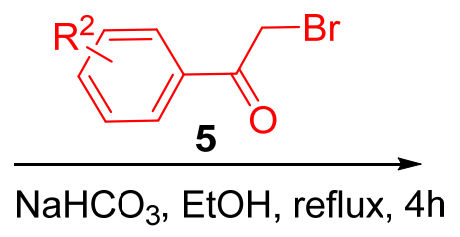

$\mathbf{5 a} \mathrm{R}^{2}=\mathrm{H}$

$\mathbf{5 b} \mathrm{R}^{2}=4-\mathrm{F}$

$5 c R^{2}=4-C l$

5d $\mathrm{R}^{2}=4-\mathrm{Br}$

5 e $R^{2}=4-M e$

$5 \mathbf{f} \mathrm{R}^{2}=2-\mathrm{OMe}$

$\mathbf{5 g ~ \mathrm { R } ^ { 2 }}=4-\mathrm{OMe}$

5h $\mathrm{R}^{2}=3,4-\mathrm{Cl}$

$5 \mathbf{i} \mathrm{R}^{2}=2,4-\mathrm{C}_{2} \mathrm{H}_{4}$<smiles>[R]c1ccc(-c2cn3c(=O)c(C#N)c(-c4cccc([R])c4)nc3[nH]2)cc1</smiles>

6
6a $R^{1}=H, R^{2}=H$
$6 \mathrm{R}^{1}=2,5-\mathrm{OCH}_{3}, \mathrm{R}^{2}=4-\mathrm{F}$
6b $\mathrm{R}^{1}=\mathrm{H}, \mathrm{R}^{2}=4-\mathrm{F}$
$6 \mathrm{~m} \mathrm{R} \mathrm{R}^{1}=2,5-\mathrm{OCH}_{3}, \mathrm{R}^{2}=4-\mathrm{Cl}$
6c $\mathrm{R}^{1}=\mathrm{H}, \mathrm{R}^{2}=4-\mathrm{Cl}$
6n $\mathrm{R}^{1}=2,5-\mathrm{OCH}_{3}, \mathrm{R}^{2}=4-\mathrm{OMe}$
6d $R^{1}=H, R^{2}=4-B r$
6 o $\mathrm{R}^{1}=3,4,5-\mathrm{OCH}_{3}, \mathrm{R}^{2}=\mathrm{H}$
6e $R^{1}=H, R^{2}=4-M e$
6 p R $\mathrm{R}^{1}=3,4,5-\mathrm{OCH}_{3}, \mathrm{R}^{2}=4-\mathrm{Cl}$
6f $\mathrm{R}^{1}=\mathrm{H}, \mathrm{R}^{2}=2-\mathrm{OMe}$
6q $\mathrm{R}^{1}=3,4,5-\mathrm{OCH}_{3}, \mathrm{R}^{2}=4-\mathrm{Br}$
6g $\mathrm{R}^{1}=\mathrm{H}, \mathrm{R}^{2}=3,4-\mathrm{Cl}$
6r $\mathrm{R}^{1}=3,4,5-\mathrm{OCH}_{3}, \mathrm{R}^{2}=4-\mathrm{Me}$
6h $\mathrm{R}^{1}=\mathrm{H}, \mathrm{R}^{2}=2,4-\mathrm{C}_{2} \mathrm{H}_{4}$
6s $\mathrm{R}^{1}=3,4,5-\mathrm{OCH}_{3}, \mathrm{R}^{2}=2-\mathrm{OMe}$
6i $\mathrm{R}^{1}=4-\mathrm{OCH}_{3}, \mathrm{R}^{2}=4-\mathrm{F}$
6t $\mathrm{R}^{1}=3,4,5-\mathrm{OCH}_{3}, \mathrm{R}^{2}=3,4-\mathrm{Cl}$
6j $\mathrm{R}^{1}=4-\mathrm{OCH}_{3}, \mathrm{R}^{2}=4-\mathrm{Cl}$
6u R $\mathrm{R}^{1}=3,4,5-\mathrm{OCH}_{3}, \mathrm{R}^{2}=2,4-\mathrm{C}_{2} \mathrm{H}_{4}$
6k $\mathrm{R}^{1}=4-\mathrm{OCH}_{3}, \mathrm{R}^{2}=4-\mathrm{OMe}$

Scheme 1. Synthesis of imidazopyrimidines 6a-u.

Based on the higher reactivity of $3-\mathrm{NH}$ over $1-\mathrm{NH}[22,30]$ it is postulated that the reaction between 4 and $\mathbf{5}$ proceeds through the initial base-catalyzed nucleophilic substitution reaction of 3 -NH of the pyrimidine moiety of $\mathbf{4}$ with 2-bromoacetophenone 5 to give a tautomeric mixture of the intermediates A and B. Subsequent intramolecular condensation between the 2-amino group of $\mathbf{B}$ with $\mathrm{C}=\mathrm{O}$ afforded the final product $\mathbf{6}$ exclusively (Scheme 2). 

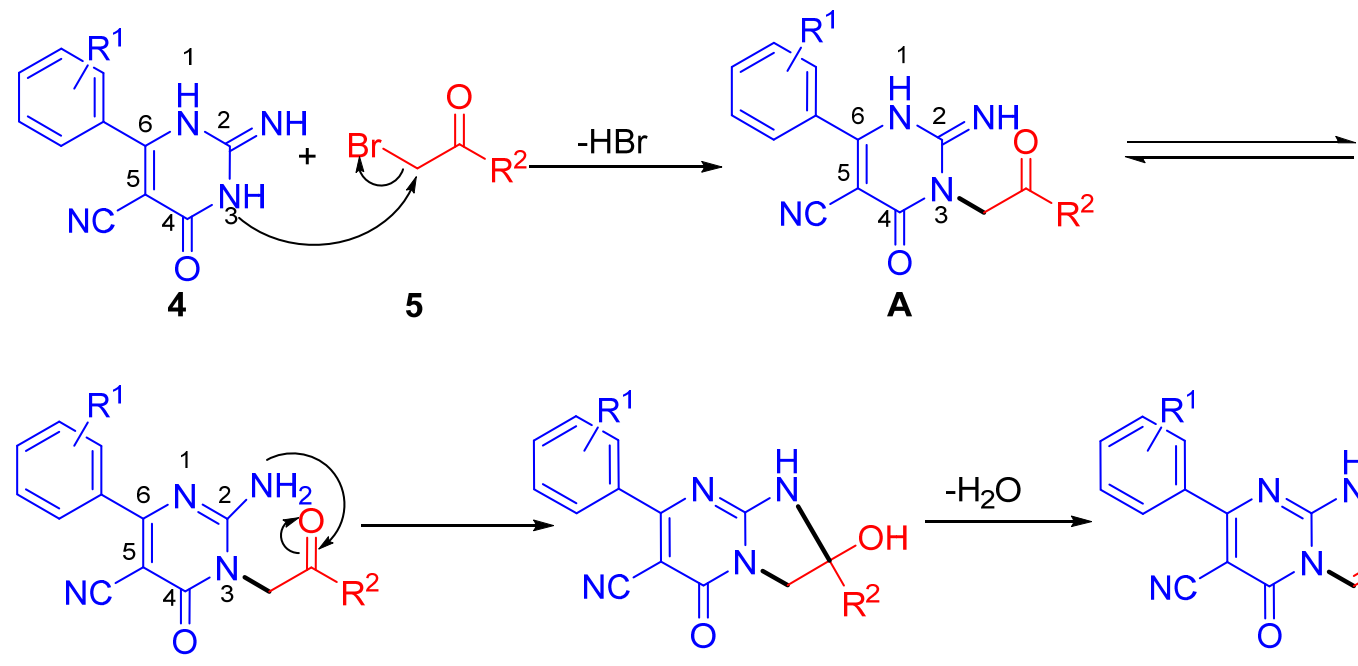

B<smiles>[R]C1(O)Cn2c(nc(-c3[R]cccc3)c(C#N)c2=O)N1</smiles>

C<smiles>[R]c1cn2c(=O)c(C#N)c(-c3[R]cccc3)nc2[nH]1</smiles>

6

Scheme 2. Proposed mechanism for the synthesis of $\mathbf{6}$.

The structures of 6a-u were elucidated by NMR spectroscopic methods including 2D NMR as well as X-ray crystallographic study. Analysis of the ${ }^{1} \mathrm{H}$ NMR spectrum of the reaction between 4 and 2-bromoacetophenones 5 revealed the formation of $\mathbf{6}$ as an exclusive product. Taking $\mathbf{6 p}$ as an example, ${ }^{1} \mathrm{H}$ NMR spectrum showed the presence of three singlets at $\delta_{\mathrm{H}} 3.76,3.85$ and 7.23 ppm corresponding to 4-OMe, 3,5-OMe, $\mathrm{H}-2^{\prime \prime}$ and $\mathrm{H}-6$ " of ring $\mathrm{A}$, respectively; their corresponding directly bonded carbons were identified by gHSQC at $\delta_{\mathrm{C}} 56.00,60.18$ and 106.24 ppm, respectively. The complete assignment of rings A-D were carried out by gHMBC ${ }^{1} \mathrm{H}-{ }^{13} \mathrm{C}$ correlations optimized for $J_{\mathrm{CH}}=8 \mathrm{~Hz}$. A strong ${ }^{3} J$ correlation between three OMe groups at ring A to C-3"', C-4" and C-5" allowed the assignment of the later at $\delta \mathrm{C} 152.49,139.56,152.49 \mathrm{ppm}$, respectively. gHMBC showed a strong ${ }^{3} J$ correlation between $\mathrm{H}-2^{\prime \prime}, \mathrm{H}-6^{\prime \prime}$ and C-7 which allows its assignment at $165.82 \mathrm{ppm} .{ }^{1} \mathrm{H}$ NMR spectrum shows two doublets at $\delta_{\mathrm{H}} 7.59$ and $7.99 \mathrm{ppm}$ corresponding to H-3', H-5' and H-2', H-6', respectively of ring D. Using gHMBC and gHSQC correlations C-2', C-6' and C-3', C-5' were assigned at $\delta_{\mathrm{C}} 127.18$ and 129. 20 ppm, respectively. Strong correlations were seen from H-3' and H-5' to C-1' with H-2', H-6', H-3', and H-5' correlating C-4' which confirms the assignment of C-1' and C-4' at $\delta \mathrm{C} 130.77$ and $134.01 \mathrm{ppm}$, respectively. A singlet at $\delta_{\mathrm{H}} 8.49 \mathrm{ppm}$ corresponding to $\mathrm{H}-3$, its directly bonded carbon was detected by gHSQC at $\delta_{\mathrm{C}} 105.12 \mathrm{ppm}$. The quaternary carbons C-2 and C-8a (ring C) were identified by gHMBC correlations; the ${ }^{3} J$ correlation between H-2', H-6' $\left(\delta_{\mathrm{H}} 7.99 \mathrm{ppm}\right)$ and C-2 established its assignment at $\delta$ C $131.68 \mathrm{ppm}$ whereas a ${ }^{3} J$ correlations from $3-\mathrm{H}$ to $\mathrm{C}-8 \mathrm{a}$ confirm 
its assignments at $\delta_{\mathrm{C}} 146.99 \mathrm{ppm}$, respectively. The remaining quaternary carbon $\mathrm{C}-6, \mathrm{C}=\mathrm{O}$ and $\mathrm{CN}$ groups were assigned at $\delta \mathrm{C} 82.64,156.53$ and $117.69 \mathrm{ppm}$, respectively by exclusion (Figure $3)$.

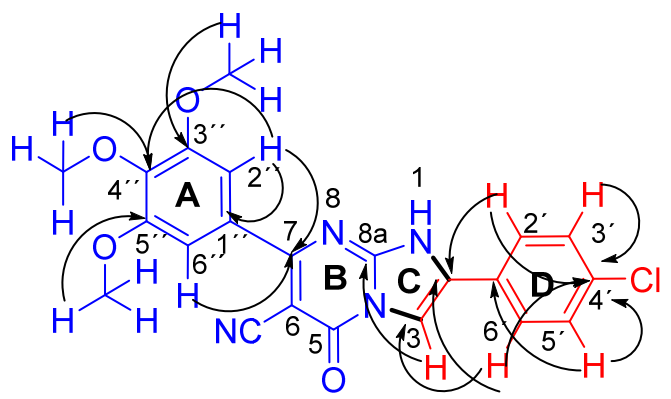

Figure 3. Important gHMBC correlations in $\mathbf{6 p}$.

In addition, unequivocal evidence for the structure of $\mathbf{6 0}$ was provided by X-ray crystal structure analysis and the molecular structure of $\mathbf{6 0}$ is depicted in Figure 4 (for full atom labeling, see supporting information Figure 20). In this structure there are a few features of key interest, namely an intramolecular short hydrogen contact, the solvent $(\mathrm{MeOH})$ hydrogen bonding network formation, and $\pi$-stacking interactions. The intramolecular short hydrogen contact between $\mathrm{C} 14-\mathrm{H} 14 \cdots \mathrm{N} 4\left(2.548(6) \AA, 149.6(9)^{\circ}\right)$ results from the almost co-planar orientation of the $\mathrm{A}$ and $\mathrm{B}$ rings (angle between the planes is $6.2(2)^{\circ}$ ). As the contact distance is larger than the expected bonding length for a hydrogen bond and the cyano moiety is pointing away from the $\mathrm{CH}$ group it is clear that this interaction is coincidental of the planar orientation and not its driving force. When looking down the $a c$-plane a linear arrangement of individual molecular units is formed. A linear hydrogen bonding network centered on the imidazopyrimidine ring from the cyano group of one molecule to the amine of its nearest neighbor can be observed. This is facilitated by the incorporation $\mathrm{MeOH}$ solvent molecule between the imidazopyrimidine rings with the amine moiety bonding to the oxygen of the $\mathrm{MeOH}$ and the cyano motif interacting with

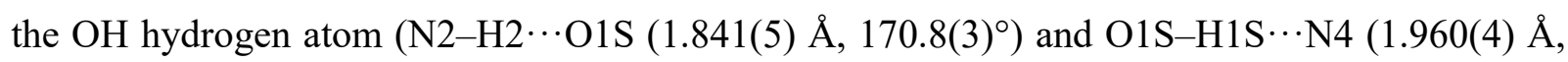
$\left.176.1(7)^{\circ}\right)$, supporting information Figure 21$)$. In the crystal packing one of the major features observed is the extensive $\pi$-stacked system (supporting information Figure 22). This due to the individual layers of the crystal lattice being rotated at $\sim 180^{\circ}$ to each other, with the trimethoxybenzene and imidazopyrimidine rings alternately stacking with each other when viewed down the $b$-axis. As a result of this high planarity within these compounds, it is clear that the formation of such $\pi$-stacked networks is a favorable interaction. 


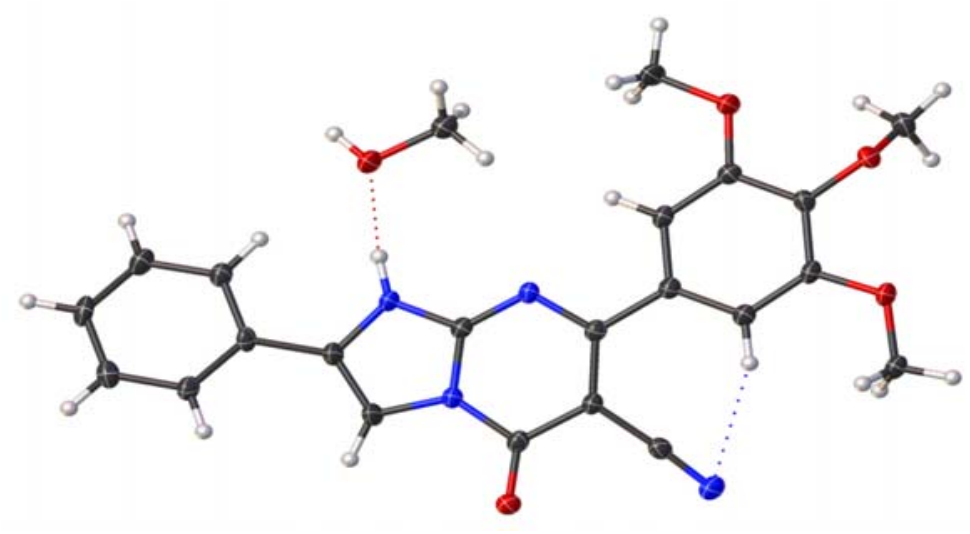

Figure 4. Molecular structure of 5-oxo-2-phenyl-7-(3,4,5-trimethoxyphenyl)-1,5dihydroimidazo[1,2-a]pyrimidine-6-carbonitrile (6o) (thermal displacement 50\%).

After the successful synthesis of $\mathbf{6 a - u}$, the synthesis of $\mathbf{9 a - d}$ was achieved by initial construction of crucial starting material 8a-c through a base-catalyzed condensation between guanidine hydrochloride (1) and $B$-ketoesters 7a-c in the presence of KOH. Subsequently, 8a-c were reacted with different 2-bromoacetophenones $\mathbf{5 b , c}$ to give the compounds 9a-d as single products (Scheme 3).<smiles>[R]C(=O)CC(=O)OCC</smiles>

1 7<smiles>[R][C]1CC(=O)NC(=N)N1</smiles>

$$
\begin{aligned}
& 7 a R^{1}=M e \\
& 7 b R^{1}=E t \\
& 7 c R^{1}=P h
\end{aligned}
$$$$
8 \mathbf{a} R^{1}=M e
$$$$
\mathbf{8 b} \mathrm{R}^{1}=\mathrm{Et}
$$$$
8 c R^{1}=P h
$$
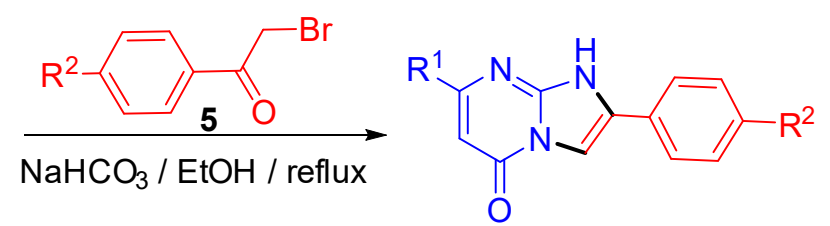

$$
\begin{aligned}
& \mathbf{5 b} \mathrm{R}^{2}=\mathrm{F} \\
& \mathbf{5 c} \mathrm{R}^{2}=\mathrm{Cl}
\end{aligned}
$$

$$
\begin{aligned}
& \text { 9a } R^{1}=\mathrm{Me}, \mathrm{R}^{2}=\mathrm{Cl} \\
& \mathbf{9 b} \mathrm{R}^{1}=\mathrm{Et}, \mathrm{R}^{2}=\mathrm{F} \\
& \mathbf{9 c} \mathrm{R}^{1}=\mathrm{Et}, \mathrm{R}^{2}=\mathrm{Cl} \\
& \mathbf{9 d \mathrm { d } ^ { 1 }}=\mathrm{Ph}, \mathrm{R}^{2}=\mathrm{F}
\end{aligned}
$$

Scheme 3. Synthesis of the target imidazo[1,2-a]pyrimidines 9a-d. 


\subsection{Biological Evaluation}

\subsubsection{In vitro antimicrobial activity}

In the present study, in vitro evaluation of the antimicrobial activities of all the synthesized imidazopyrimidines 6a-u and 9a-d against two Gram (+) bacteria $(S$. aureus ATTCC 6538 and $B$. subtilis ATCC 663) and four Gram (-) bacteria (E. coli ATTCC 8739, P. aeruginosa ATCC 9027, S. typhi ATCC 14028 and K. pneumonia ATCC10131) were performed employing agar well diffusion technique $[31,32]$. Ampicillin and levofloxacin were used as reference drugs for Gram $(+)$ and Gram (-) bacteria, respectively. The diameters of the inhibition zones (mm) subsequent to treatment with $100 \mu \mathrm{L}$ of $10 \mathrm{mg} / \mathrm{mL}$ of $\mathbf{6 a - u}$ and $9 \mathbf{a}-\mathbf{d}$ as well as the positive controls are presented in Table 1. 
Table 1: Antimicrobial activities of 6a-u, 9a-d and positive controls expressed as diameters of inhibition zone (mm).

\begin{tabular}{|c|c|c|c|c|c|c|c|}
\hline \multirow{3}{*}{ Entry } & \multirow{3}{*}{ Product } & \multicolumn{6}{|c|}{ Diameter of Inhibition zone $(\mathrm{mm})$} \\
\hline & & \multicolumn{2}{|l|}{$\operatorname{Gram}(+)$} & \multicolumn{4}{|l|}{ Gram (-) } \\
\hline & & S. aureus & B. subtilis & E. coli & P. aeruginosa & K. pneumonia & S. typhi \\
\hline 1 & 6a & $11 \pm 0.0$ & $14 \pm 0.7$ & $11.5 \pm 0.7$ & $35 \pm 1.4$ & $19 \pm 5.7$ & $14 \pm 0.0$ \\
\hline 2 & $6 \mathbf{b}$ & $15 \pm 0.7$ & $21 \pm 0.7$ & $16 \pm 2.8$ & - & $15 \pm 0.7$ & - \\
\hline 3 & $6 c$ & $16.5 \pm 0.7$ & $19 \pm 0.0$ & $20.5 \pm 0.7$ & $40 \pm 0.7$ & $34.5 \pm 3.5$ & $23.5 \pm 0.7$ \\
\hline 4 & 6d & $13 \pm 0.0$ & $20 \pm 1.4$ & $11 \pm 0.0$ & - & $16.5 \pm 0.7$ & $18.5 \pm 0.7$ \\
\hline 5 & $6 e$ & - & $18 \pm 1.4$ & $12 \pm 0.0$ & $12 \pm 0.0$ & $16 \pm 2.8$ & $15 \pm 0.0$ \\
\hline 6 & 6f & $13 \pm 0.0$ & $17 \pm 2.1$ & $20.5 \pm 0.7$ & $16 \pm 0.7$ & $14.5 \pm 0.7$ & $16.5 \pm 0.7$ \\
\hline 7 & $6 \mathrm{~g}$ & $13.5 \pm 0.7$ & $16 \pm 0.7$ & $17.5 \pm 0.7$ & $12 \pm 0.7$ & $17.5 \pm 2.1$ & $15.5 \pm 2.1$ \\
\hline 8 & $6 h$ & - & - & $11 \pm 0.0$ & $15 \pm 0.7$ & $16.5 \pm 0.7$ & $18 \pm 2.8$ \\
\hline 9 & $6 \mathbf{i}$ & - & $32 \pm 0.7$ & - & $15 \pm 1.4$ & $12 \pm 0$ & - \\
\hline 10 & $6 \mathbf{j}$ & $17 \pm 2.1$ & $25 \pm 1.4$ & $20 \pm 0$ & - & $20 \pm 0.7$ & $14 \pm 0.7$ \\
\hline 11 & $6 \mathbf{k}$ & - & $45 \pm 0.7$ & - & - & - & - \\
\hline 12 & 61 & - & - & - & - & - & $14 \pm 1.4$ \\
\hline 13 & $6 m$ & - & - & - & - & $12 \pm 0$ & $20 \pm 2.8$ \\
\hline 14 & 6n & - & - & - & - & - & - \\
\hline 15 & 60 & - & $11 \pm 0.7$ & - & - & $16 \pm 0.0$ & $19.5 \pm 0.7$ \\
\hline 16 & $6 p$ & - & - & - & - & $17 \pm 0.0$ & $16 \pm 1.4$ \\
\hline 17 & $6 q$ & - & - & $13 \pm 0.0$ & $11 \pm 2.1$ & $15.5 \pm 0.7$ & $18 \pm 1.4$ \\
\hline 18 & $6 r$ & - & $12 \pm 0.0$ & $11.5 \pm 0.7$ & - & $19 \pm 0.0$ & $16.5 \pm 0.7$ \\
\hline 19 & $6 s$ & - & - & $11 \pm 0.0$ & - & $18 \pm 0.0$ & $14.5 \pm 0.7$ \\
\hline 20 & $6 t$ & - & - & - & - & $20 \pm 0.0$ & $14.5 \pm 0.7$ \\
\hline 21 & $6 u$ & - & - & - & - & $16 \pm 0.0$ & $15 \pm 1.4$ \\
\hline 22 & 9a & - & - & - & - & $15.5 \pm 0.7$ & $14 \pm 0.0$ \\
\hline 23 & $9 \mathrm{~b}$ & $20 \pm 0.7$ & - & $25 \pm 1.4$ & $17 \pm 0$ & $11 \pm 1.4$ & $15 \pm 0.7$ \\
\hline 24 & $9 c$ & - & - & - & - & $15.5 \pm 0.7$ & $16 \pm 1.4$ \\
\hline 25 & 9d & - & $19 \pm 2.1$ & - & $15 \pm 2.1$ & $14 \pm 0$ & $20 \pm 1.4$ \\
\hline 26 & Amipicllin & $12 \pm 0.7$ & $13 \pm 0.0$ & nd & nd & nd & nd \\
\hline 27 & Levofloxacin & nd & nd & 20 & $14 \pm 1.4$ & $20 \pm 2.0$ & $11 \pm 0.0$ \\
\hline 28 & DMSO & - & - & - & - & - & - \\
\hline
\end{tabular}

From the results depicted in Table 1, most of the synthesized imidazopyrimidines 6a-u and 9a-d showed promising zones of inhibition against Gram (-) bacteria over Gram (+) ones. Concerning the Gram (+) bacteria, B. subtilis is much more sensitive to the effect of synthesized compounds rather than $S$. aureus. Most of the compounds having unsubstituted phenyl group 6a-g at seven position showed moderate to potent antimicrobial activity against $S$. aureus, while complete loss of activity was observed upon introducing methoxyphenyl groups in $\mathbf{6 i}, \mathbf{6 k}-\mathbf{u}$. Compounds $\mathbf{6 e}, \mathbf{6 h}$ and $\mathbf{6 j}$ are the only exceptions. Meanwhile, compounds $\mathbf{6 i - k}$ with a 4-methoxyphenyl group at the seven position were more potent than $\mathbf{6 a - g}$ against $B$. subtilis. Compounds $\mathbf{6 b - d}, \mathbf{6 f}, \mathbf{6 g}, \mathbf{6 j}, \mathbf{9 b}$ 
showed wider zones of inhibition than ampicillin against $S$. aureus, whereas 6a-g, 6i-k, 9d demonstrated larger inhibition zones than ampicillin against B. subtilis. Regarding Gram (-) bacteria, most of the tested compounds possess significant antibacterial activity against $K$. pneumonia and S. typhi in comparison to their effect on E. coli and P. aeruginose. Again most of the compounds exhibiting unsubstituted phenyl group at seven position 6a-h showed moderate to potent antimicrobial activity against $E$. coli and $P$. aeruginose, while decrease or complete loss of activity was observed upon introducing methoxyphenyl groups. Compounds $\mathbf{6 j}$ and $\mathbf{6 q}$ are exceptions. Compounds $\mathbf{6 c}, \mathbf{6 f}, \mathbf{6 j}$ and $\mathbf{9 b}$ were equipotent or more potent than levofloxacin against E. coli, while $\mathbf{6 a}, \mathbf{6 c}, \mathbf{6} \mathbf{f}, \mathbf{6 h}, \mathbf{6 i}, \mathbf{9 b}$ and $9 \mathbf{d}$ showed wider zones of inhibition than levofloxacin against $P$. aeruginosa. Nearly all of the tested imidazopyrimidines demonstrated promising activity against $K$. pneumonia and $S$. typhi in comparison to levofloxacin. Compound 6c showed the widest zone of inhibition against the two bacterial strains.

Based on the obtained results, the minimum inhibitory concentration (MIC) of the synthesized imidazopyrimidines that showed antimicrobial activity was determined by employing a twofold serial dilution technique $[31,32]$. The lowest concentration that showed no growth inhibition was determined as the MIC and the obtained results are presented in Table 2.

Analysis of the obtained results revealed that some imidazopyrimidines have significant inhibitory effects against Gram (+) and Gram (-) bacteria with MIC up to $10 \mu \mathrm{g} / \mathrm{mL}$. The effect of the substituents at the two position demonstrated that compound $\mathbf{6 c}$ with $p$-chlorophenyl group exhibited promising antimicrobial activity against all tested bacteria.

None of the tested imidazopyrimidines showed higher activity than ampicillin against $S$. aureus. From the obtained results it obvious that introduction of 4-F phenyl group in $6 \mathbf{b}$ (MIC $=500$ $\mu \mathrm{g} / \mathrm{mL})$ or 3,4-dichlorophenyl group in $\mathbf{6 g}(\mathrm{MIC}=500 \mu \mathrm{g} / \mathrm{mL})$ resulted in no change in the antibacterial activity when compared to $\mathbf{6 a}(\mathrm{MIC}=500 \mu \mathrm{g} / \mathrm{mL})$, whereas introduction of 4-Cl phenyl moiety in $\mathbf{6 c}(\mathrm{MIC}=50 \mu \mathrm{g} / \mathrm{mL})$ or 2-methoxyphenyl group in $\mathbf{6 f}(\mathrm{MIC}=50 \mu \mathrm{g} / \mathrm{mL})$ resulted in tenfold increase in the potency. Replacement of the 4-chlorophenyl group of $\mathbf{6 c}$ (MIC $=50 \mu \mathrm{g} / \mathrm{mL})$ with 4-bromo derivative in $\mathbf{6 d}(\mathrm{MIC}=2500 \mu \mathrm{g} / \mathrm{mL})$ resulted in 50 -fold decrease in the potency while replacement with 4-tolyl moiety in $6 \mathbf{e}$ or naphthyl moiety in $\mathbf{6 h}$ showed total loss of the antibacterial activity against $S$. aureus. 
The MIC results of the synthesized imidazopyrimidines on B. subtilis demonstrated that $\mathbf{6 g}$ (MIC $=10 \mu \mathrm{g} / \mathrm{mL})$ have higher potency than ampicillin $(\mathrm{MIC}=12.5 \mu \mathrm{g} / \mathrm{mL})$. Introduction of 4-F phenyl group in $\mathbf{6 b}(\mathrm{MIC}=500 \mu \mathrm{g} / \mathrm{mL})$, 4-tolyl group in $\mathbf{6 e}(\mathrm{MIC}=500 \mu \mathrm{g} / \mathrm{mL})$ resulted in no change in the potency when compared to the 2-phenyl derivative 6a $(\mathrm{MIC}=500 \mu \mathrm{g} / \mathrm{mL}$ ). Whereas compounds 6c, 6d and 6f which exhibit 4-chlorophenyl, 4-bromophenyl and 2methoxyphenyl groups, respectively showed tenfold increase in the activity (MIC $=50 \mu \mathrm{g} / \mathrm{mL}$ ). Further introduction of 3,4-dichlorophenyl group in $\mathbf{6 g}(\mathrm{MIC}=10 \mu \mathrm{g} / \mathrm{mL})$ demonstrated fivefold increase in the potency in comparison to $\mathbf{6 c}(\mathrm{MIC}=50 \mu \mathrm{g} / \mathrm{mL})$. Replacement of the phenyl moiety in $\mathbf{6 a}$ with naphthyl moiety in $\mathbf{6} \mathbf{h}$ resulted in complete loss of activity. In series $\mathbf{6 i - k}$, compound $\mathbf{6 j}$ with $p$-chlorophenyl group at the two position showed $\mathrm{MIC}=50 \mu \mathrm{g} / \mathrm{mL}$. Replacement of the 4-chlorophenyl group in $\mathbf{6 j}(\mathrm{MIC}=50 \mu \mathrm{g} / \mathrm{mL})$ with 4-fluorophenyl in $\mathbf{6} \mathbf{i}$ $(\mathrm{MIC}=100 \mu \mathrm{g} / \mathrm{mL})$ or 4-methoxyphenyl group in $\mathbf{6 k}(\mathrm{MIC}=500 \mu \mathrm{g} / \mathrm{mL})$ resulted in twofold and fivefold decrease in the potency, respectively.

Compounds $\mathbf{6 c}(\mathrm{MIC}=10 \mu \mathrm{g} / \mathrm{mL}), \mathbf{6 g}(\mathrm{MIC}=10 \mu \mathrm{g} / \mathrm{mL})$ with chlorophenyl groups and $\mathbf{6 f}(\mathrm{MIC}$ $=12.5 \mu \mathrm{g} / \mathrm{mL}$ ) with a 2-methoxyphenyl moiety at the two position are slightly less potent to levofloxacin $(\mathrm{MIC}=6.25 \mu \mathrm{g} / \mathrm{mL}$ ) against E-coli, while $\mathbf{6 d}$, $\mathbf{6 j}$ and $9 \mathbf{b}$ showed moderate antibacterial activity (MIC $=50 \mu \mathrm{g} / \mathrm{mL}$ ). Replacement of phenyl group at the two position of $6 \mathbf{6}$ $(\mathrm{MIC}=500 \mu \mathrm{g} / \mathrm{mL})$ with 4-F phenyl group in $\mathbf{6 b}, 4$-tolyl group in $\mathbf{6 e}$ or naphthyl group in $\mathbf{6 h}$ resulted in no change in the activity ( $\mathrm{MIC}=500 \mu \mathrm{g} / \mathrm{mL}$ ), while tenfold increase in the potency was observed by introduction of 4-Br phenyl group in $\mathbf{6 d}(\mathrm{MIC}=50 \mu \mathrm{g} / \mathrm{mL})$. Further increase in the potency appeared in $\mathbf{6} \mathbf{f}(\mathrm{MIC}=12.5 \mu \mathrm{g} / \mathrm{mL})$ which exhibit 2-methoxyphenyl group at the two position and it reaches its maximum potency by the incorporation of the $p$-chlorophenyl group in $\mathbf{6 c}(\mathrm{MIC}=10 \mu \mathrm{g} / \mathrm{mL})$ and 3,4-dichlorophenyl group in $\mathbf{6 g}(\mathrm{MIC}=10 \mu \mathrm{g} / \mathrm{mL})$.

Compound $6 f(\mathrm{MIC}=12.5 \mu \mathrm{g} / \mathrm{mL})$ demonstrated comparable antibacterial activity to levofloxacin $(\mathrm{MIC}=12.5 \mu \mathrm{g} / \mathrm{mL}$ ) against $P$. aeruginosa. Compound $\mathbf{6 a}$ displayed potent inhibitory activity of MIC $=50 \mu \mathrm{g} / \mathrm{mL}$, replacement of the phenyl group at the two position with 4-chlorophenyl group in $\mathbf{6 c}$ or 3,4-dichlorophenyl in $\mathbf{6 g}$ resulted no change in the activity (MIC = $50 \mu \mathrm{g} / \mathrm{mL})$ whereas its replacement with 4-tolyl moiety in $\mathbf{6 e}(\mathrm{MIC}=100 \mu \mathrm{g} / \mathrm{mL})$ or naphthyl group in $\mathbf{6 h}(\mathrm{MIC}=500 \mu \mathrm{g} / \mathrm{mL})$ resulted in twofold and fivefold decrease in the potency, respectively. Total loss of potency was observed by introduction of 4-fluorophenyl group in $\mathbf{6 b}$, or 4-bromophenyl group in $\mathbf{6 d}$. 
K. pneumonia is one of the most sensitive bacterial strains to the synthesized imidazopyrimidines. Compounds $\mathbf{6 c}$ and 9d (MIC $=12.5$ and $25 \mu \mathrm{g} / \mathrm{mL}$, respectively) showed potent antibacterial activity against $K$. pneumonia, while compounds $6 \mathbf{6}, \mathbf{6 f}, \mathbf{6 g}, \mathbf{6 p}, \mathbf{6 t}$, and $9 \mathbf{c}$ showed moderate antibacterial activity (MIC $=50 \mu \mathrm{g} / \mathrm{mL}$ ) in comparison to levofloxacin (MIC $=10 \mu \mathrm{g} / \mathrm{mL}$ ). In series 6a-h, replacement of phenyl group in $\mathbf{6 a}(\mathrm{MIC}=50 \mu \mathrm{g} / \mathrm{mL})$ with 2-methoxyphenyl group in 6 f or 3,4-dichlorophenyl group in $\mathbf{6 g}$ ( $\mathrm{MIC}=50 \mu \mathrm{g} / \mathrm{mL}$ ) resulted in no change in the activity, whereas replacement of the phenyl group in $\mathbf{6 a}(\mathrm{MIC}=50 \mu \mathrm{g} / \mathrm{mL})$ with $p$-chlorophenyl group in 6c displayed increase in the antibacterial activity $(\mathrm{MIC}=12.5 \mu \mathrm{g} / \mathrm{mL})$. On the contrary, introduction of 4-fluorophenyl moiety in $\mathbf{6 b}(\mathrm{MIC}=1000 \mu \mathrm{g} / \mathrm{mL})$, 4-bromophenyl group in $\mathbf{6 d}$ $(\mathrm{MIC}=2500 \mu \mathrm{g} / \mathrm{mL})$, 4-tolyl group in $\mathbf{6 e}(\mathrm{MIC}=100 \mu \mathrm{g} / \mathrm{mL})$ or naphthyl group in $\mathbf{6 h}(\mathrm{MIC}=$ $500 \mu \mathrm{g} / \mathrm{mL}$ ) resulted in decrease in the potency against $K$. pneumonia. In series 6o-u, replacement of phenyl group at the two position of $60(\mathrm{MIC}=500 \mu \mathrm{g} / \mathrm{mL})$ with a 4-tolyl moiety in $6 \mathbf{r}$, 2methoxyphenyl in $\mathbf{6 s}$, or naphthyl group in $\mathbf{6 u}$ resulted in no change in the potency (MIC $=500$ $\mu \mathrm{g} / \mathrm{mL}$ ), whereas tenfold increase in the activity appeared upon introduction of 4-chlorophenyl group in 6p $(\mathrm{MIC}=50 \mu \mathrm{g} / \mathrm{mL})$ and 3,4-dichlorophenyl group in $6 \mathbf{t}(\mathrm{MIC}=50 \mu \mathrm{g} / \mathrm{mL})$. The 4bromophenyl derivative 6q $(\mathrm{MIC}=1000 \mu \mathrm{g} / \mathrm{mL})$ has twofold decrease in potency in comparison to $60(\mathrm{MIC}=500 \mu \mathrm{g} / \mathrm{mL})$. In series 9a-d, compound 9d $(\mathrm{MIC}=25 \mu \mathrm{g} / \mathrm{mL})$ was the most potent compound in series $\mathbf{9}$, replacement of the phenyl group at the seven position of $\mathbf{9 d}$ with ethyl group in 9b $(\mathrm{MIC}=500 \mu \mathrm{g} / \mathrm{mL})$ resulted in 20 -fold decrease in the potency whereas further replacement of the 4-fluorophenyl group at the two position of $\mathbf{9 b}$ with 4-chlorophenyl group in $9 c(\mathrm{MIC}=50 \mu \mathrm{g} / \mathrm{mL})$ resulted in tenfold increase in the potency. Further replacement of the ethyl group at seven position of $\mathbf{9 b}(\mathrm{MIC}=500 \mu \mathrm{g} / \mathrm{mL})$ with a methyl group in 9a $(\mathrm{MIC}=2500$ $\mu \mathrm{g} / \mathrm{mL}$ ) resulted in fivefold decrease in the antibacterial activity.

S. typhi is also one of the most sensitive microorganisms to the synthesized series. The imidazopyrimidines $\mathbf{6 c}, \mathbf{6 g}, \mathbf{6 t}$ and $9 \mathbf{d}(\mathrm{MIC}=12.5 \mu \mathrm{g} / \mathrm{mL})$ were the most potent derivatives. Replacement of 2-phenyl group of $\mathbf{6 a}(\mathrm{MIC}=100 \mu \mathrm{g} / \mathrm{mL})$ with 4-bromophenyl moiety in $\mathbf{6 d}$ $(\mathrm{MIC}=50 \mu \mathrm{g} / \mathrm{mL}), 4$-tolyl in $\mathbf{6 e}(\mathrm{MIC}=50 \mu \mathrm{g} / \mathrm{mL})$ resulted in twofold increase in the activity, whereas the incorporation of 2-methoxyphenyl substituent in $\mathbf{6 f}(\mathrm{MIC}=25 \mu \mathrm{g} / \mathrm{mL})$ resulted in fourfold increase in the potency in comparison to $\mathbf{6 a}(\mathrm{MIC}=100 \mu \mathrm{g} / \mathrm{mL})$, while introduction of 4-chlorophenyl substituent in $\mathbf{6 c}(\mathrm{MIC}=12.5 \mu \mathrm{g} / \mathrm{mL})$ or 3,4-dichlorophenyl substituent in $\mathbf{6 g}$ (MIC $=12.5 \mu \mathrm{g} / \mathrm{mL}$ ) showed sixfold increase in the potency. Replacement of the phenyl group of 
6a with a naphthyl moiety in $\mathbf{6 h}(\mathrm{MIC}=500 \mu \mathrm{g} / \mathrm{mL})$ displayed fivefold decrease in the potency while introduction of 4-fluorophenyl substituent in $\mathbf{6 b}$ resulted in total loss of the activity. In series 6o-u, compound $60(\mathrm{MIC}=100 \mu \mathrm{g} / \mathrm{mL})$ with 3,4,5-trimethoxyphenyl group at the seven position has the same potency as $\mathbf{6 a}(\mathrm{MIC}=100 \mu \mathrm{g} / \mathrm{mL})$ with a phenyl group at seven position. Replacement of phenyl group at the two position of $\mathbf{6 o}(\mathrm{MIC}=100 \mu \mathrm{g} / \mathrm{mL})$ with 4-bromophenyl $\mathbf{6 q}$, 4-tolyl in 6r, 2-methoxyphenyl in $\mathbf{6 s}$, or naphthyl in $\mathbf{6 u}$ resulted in no change of the potency, whereas replacement of phenyl group of $\mathbf{6 0}(\mathrm{MIC}=100 \mu \mathrm{g} / \mathrm{mL})$ with 4-chlorophenyl in $\mathbf{6 p}$ (MIC $=25 \mu \mathrm{g} / \mathrm{mL})$ or 3,4-dichlorophenyl in $6 \mathbf{t}(\mathrm{MIC}=12.5 \mu \mathrm{g} / \mathrm{mL})$ resulted in fourfold and eightfold increase in the potency, respectively. In series 9, compounds 9a and 9b $(\mathrm{MIC}=1000 \mu \mathrm{g} / \mathrm{mL}$ ) showed weak activity while tenfold increase in potency was observed by replacement of the 4fluorophenyl group of $\mathbf{9 b}(\mathrm{MIC}=1000 \mu \mathrm{g} / \mathrm{mL})$ with 4-chlorophenyl moiety in $\mathbf{9 c}(\mathrm{MIC}=100$ $\mu \mathrm{g} / \mathrm{mL}$ ). Further replacement of the aliphatic group at seven position of 9a-c (MIC $=100-1000$ $\mu \mathrm{g} / \mathrm{mL}$ ) with a phenyl group in 9d showed more than eightfold increase in potency (MIC $=12.5$ $\mu \mathrm{g} / \mathrm{mL})$.

Table 2. Minimum inhibitory concentration MICs $(\mu \mathrm{g} / \mathrm{mL})$ of synthesized imidazopyrimidines compared to ampicillin and levofloxacin as positive controls. 


\begin{tabular}{|c|c|c|c|c|c|c|c|}
\hline \multirow{3}{*}{ Entry } & \multirow{3}{*}{ Product } & \multicolumn{6}{|c|}{ Minimum Inhibitory Concentration $(\mu \mathrm{g} / \mathrm{mL})$} \\
\hline & & \multicolumn{2}{|c|}{ Gram (+) } & \multicolumn{4}{|c|}{ Gram (-) } \\
\hline & & S. aureus & B. subtilis & E. coli & P.aeruginosa & K. pneumonia & S.typhi \\
\hline 1 & 6a & 500 & 500 & 500 & 50 & 50 & 100 \\
\hline 2 & 6b & 500 & 500 & 500 & - & 1000 & - \\
\hline 3 & 6c & 50 & 50 & 10 & 50 & 12.5 & 12.5 \\
\hline 4 & 6d & 2500 & 50 & 50 & - & 2500 & 50 \\
\hline 5 & $6 e$ & - & 500 & 500 & 100 & 100 & 50 \\
\hline 6 & $6 f$ & 50 & 50 & 12.5 & 12.5 & 50 & 25 \\
\hline 7 & $6 \mathrm{~g}$ & 500 & 10 & 10 & 50 & 50 & 12.5 \\
\hline 8 & $6 h$ & - & - & 500 & 500 & 500 & 500 \\
\hline 9 & $6 \mathbf{i}$ & - & 100 & - & 500 & 500 & - \\
\hline 10 & $6 \mathbf{j}$ & 500 & 50 & 50 & - & 1000 & 500 \\
\hline 11 & $6 \mathrm{k}$ & - & 500 & - & - & - & - \\
\hline 12 & 61 & - & - & - & - & - & 25 \\
\hline 13 & $6 m$ & - & - & - & - & 2500 & 500 \\
\hline 14 & $6 n$ & - & - & - & - & - & - \\
\hline 15 & 60 & - & 500 & - & - & 500 & 100 \\
\hline 16 & $6 p$ & - & - & - & - & 50 & 25 \\
\hline 17 & $6 q$ & - & - & 1000 & 1000 & 1000 & 100 \\
\hline 18 & $6 r$ & - & 500 & 500 & - & 500 & 100 \\
\hline 19 & $6 s$ & - & . & 500 & - & 500 & 100 \\
\hline 20 & $6 t$ & - & - & - & - & 50 & 12.5 \\
\hline 21 & $6 u$ & - & - & - & - & 500 & 100 \\
\hline 22 & $9 a$ & - & - & - & - & 2500 & 1000 \\
\hline 23 & $9 b$ & 100 & - & 50 & 500 & 500 & 1000 \\
\hline 24 & $9 c$ & - & - & - & - & 50 & 100 \\
\hline 25 & $9 d$ & - & 50 & - & 50 & 25 & 12.5 \\
\hline 26 & Ampicllin & 6.25 & 12.5 & n.d. & n.d. & n.d. & n.d. \\
\hline 27 & Levofloxacin & n.d. & n.d. & 6.25 & 12.5 & 10 & 3.13 \\
\hline 28 & DMSO & - & - & - & - & - & - \\
\hline
\end{tabular}

\subsubsection{In vitro inhibitory activity on $E$. coli GyrB ATPase}

The most potent compounds $\mathbf{6 c}, \mathbf{6 d}, \mathbf{6 f}, \mathbf{6} \mathbf{g}$ and $9 \mathbf{d}$, as well as novobiocin, were evaluated for their GyrB ATPase inhibitory activity using E. coli Gyrase for ATPase assays kit according to the manufacturers' protocol (Inspiralis Ltd, England) and the results are presented in Table 3. From the obtained results, it is obvious that the imidazopyrimidine derivatives $\mathbf{6 c}, \mathbf{6 f}$ and $\mathbf{6 g}$ bearing 4chlorophenyl, dichlorophenyl or 2-methoxyphenyl substituents at the two position showed GyrB 
ATPase inhibitory activity of $\mathrm{IC}_{50}=1.52,1.14$ and $0.73 \mu \mathrm{M}$, respectively in comparison to novobiocin $\left(\mathrm{IC}_{50}=0.05 \mu \mathrm{M}\right)$, while compounds $6 \mathbf{d}$ and $9 \mathbf{d}$ showed $\mathrm{IC}_{50}>10 \mu \mathrm{M}$.

Table 3. Inhibitory activity of imidazopyrimidines on E. coli gyrase B ATPase.

\begin{tabular}{llc}
\hline Entry & Compound & $\mathrm{IC}_{50}(\mu \mathrm{M})^{a}$ on GyrB ATPase \\
\hline 1 & 6c & 1.52 \\
2 & 6d & $>10$ \\
3 & 6f & 1.14 \\
4 & $\mathbf{6 g}$ & 0.73 \\
5 & $\mathbf{9 d}$ & $>10$ \\
6 & Novobiocin & 0.05
\end{tabular}

${ }^{a}$ Results are average of two independent experiments

\subsubsection{In-vitro antiproliferative activity against NCI 60-cell line panel}

Some of the synthesized imidazopyrimidines were screened for their in vitro antiproliferative activity through the Developmental Therapeutics Program (DTP) of the National Cancer Institute (NCI) in the division of cancer treatment and diagnosis, NIH, Bethesda, Maryland, USA (www.dtp.nci.nih.gov). This involved screening the synthesized compounds at a single dose of 10 $\mu \mathrm{M}$ against a full NCI 60 cell panel including leukemia, melanoma, lung, colon, brain, ovary, kidney, prostate and breast cancers. The results are presented in Table 4.

Table 4. In vitro growth inhibition \% (GI \%) of the selected compounds against a panel of tumor cell lines at $10 \mu \mathrm{M}$.

\begin{tabular}{cccccccccc}
\hline Subpanel & \multicolumn{8}{c}{ Growth Inhibition \% } \\
& $\mathbf{6 a}$ & $\mathbf{6 b}$ & $\mathbf{6 c}$ & $\mathbf{6 d}$ & $\mathbf{6 f}$ & $\mathbf{6 g}$ & $\mathbf{6 h}$ & $\mathbf{6 p}$ & $\mathbf{9 d}$ \\
\hline Leukemia & & & & & & & & & \\
CCRF-CEM & $-{ }^{-}$ & - & - & - & - & - & - & - & 44 \\
HL-60(TB) & - & - & - & - & 20 & 13 & - & 11 & 81 \\
K-562 & - & 24 & 14 & - & 13 & 11 & - & 14 & 81 \\
MOLT-4 & - & 13 & - & - & - & - & - & 11 & 60 \\
PRMI-8226 & - & - & - & - & 20 & - & - & - & 25 \\
SR & 10 & 11 & 13 & 16 & 18 & 17 & - & 27 & 84 \\
Non-small cell lung Cancer & & & & & & & & & \\
A549/ATTC & - & - & - & - & 12 & - & - & - & 34 \\
EKVX & 25 & 24 & - & - & 30 & - & - & - & 12 \\
HOP-62 & 24 & 39 & 14 & 19 & 13 & - & - & 13 & 32 \\
HOP-92 & 19 & 35 & - & - & 10 & - & - & 17 & 45
\end{tabular}




$\begin{array}{cccccccccr}\text { NCI-H226 } & 14 & 24 & - & 10 & - & - & - & - & 13 \\ \text { NCI-H23 } & 23 & 23 & - & - & 26 & - & 12 & 13 & 28 \\ \text { NCI-H322M } & 11 & - & - & - & 11 & - & - & - & - \\ \text { NCI-H460 } & - & - & - & - & 25 & - & - & - & 53 \\ \text { NCI-H522 } & 23 & 17 & 20 & 19 & 34 & 19 & 21 & 27 & 64\end{array}$

Colon Cancer

COLO 205

HCC-2998

HCT-116

HCT-15

HT29

KM12

SW-620

CNS Cancer

SF-268

SF-295

SF-539

SNB-19

SNB-75

U251

Melanoma

LOX IMVI

MALME-3M

M14

MDA-MB-435

SK-MEL-2

SK-MEL-28

SK-MEL-5

UACC-257

UACC-62

$\begin{array}{lllll}23 & 17 & 20 & 19 & 34\end{array}$

$\begin{array}{llllllll}- & - & - & - & - & - & - & -\end{array}$

$\begin{array}{lllllllll}17 & 15 & - & - & 20 & - & - & - & 24\end{array}$

$13 \quad-\quad-\quad 18 \quad 21$

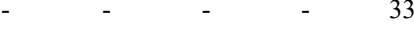

$\begin{array}{lllll}10 & 13 & - & 10 & 25\end{array}$

$\begin{array}{llll}-1 & - & - & 49 \\ - & - & - & 62\end{array}$

$12 \quad 59$

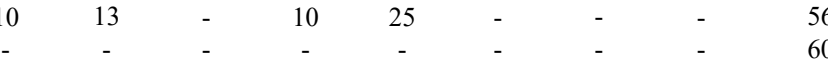

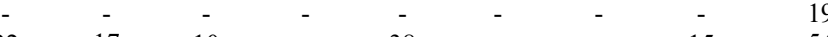

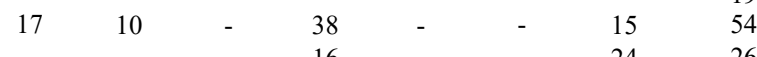

$\begin{array}{llllllll}- & - & - & 16 & - & - & 24 & 26\end{array}$

$\begin{array}{lllllllll}21 & 20 & 23 & 30 & 30 & 26 & - & - & 32 \\ - & 11 & - & - & 14 & - & - & - & 44\end{array}$

Ovarian Cancer

IGROV1

OVCAR-3

OVCAR-4

OVCAR-5

OVCAR-8

NCI/ADR-RES

SK-OV-3

Renal Cancer

$\begin{array}{cccccccccc}786-0 & - & - & - & - & 20 & - & - & 11 & 21 \\ \text { A498 } & - & - & - & - & 46 & - & - & 16 & 41 \\ \text { ACHN } & 17 & 14 & - & - & 15 & - & - & 13 & 12 \\ \text { CAKI-1 } & 17 & 31 & 19 & 23 & - & 10 & - & 27 & 52 \\ \text { RXF 393 } & - & - & - & - & - & - & - & - & 28 \\ \text { SN 12C } & - & 10 & - & - & - & - & - & - & 11 \\ \text { TK-10 } & - & - & - & - & - & - & - & - & - \\ \text { UO-31 } & 35 & 39 & 35 & 30 & 33 & 19 & 13 & 33 & 31\end{array}$

Prostate Cancer

PC-3
DU-145
Breast Cancer

PC-3
DU-145
Breast Cancer

$\begin{array}{lllll}13 & 11 & - & - & 20\end{array}$

$\begin{array}{llll}- & 12 & 13 & 20 \\ - & 10 & - & 18\end{array}$

27

$49 \quad 21 \quad 20$

$14 \quad 11$

- 14

- $\quad-$

- 786

$25 \quad 25$

MCF7

MDA-MB-231/ATTC

HS 578T

BT-549

$\mathrm{T}-47 \mathrm{D}$

MDA-MB-468

$\%$ of growth inhibition is less than $10 \%$ 
From the obtained results, it was clear that each of the synthesized imidazopyrimidine have different degree of efficiency against 60 cancer cell lines. NCI-H522 from non-small cell lung cancer, SNB-75 from CNS cancer, UO-31 from renal cancer, and MCF-7 and T-47D from breast cancer are the most sensitive cell lines to the tested imidazopyrimidines $\mathbf{6 a - d}, \mathbf{6 f - h}, \mathbf{6 p}$ and $9 \mathbf{d}$. Compound 9d showed broad spectrum of promising anti-proliferative activity against several NCI cell panels with mean growth inhibition percentage of $37 \%$. At $10 \mu \mathrm{M}$ concentration, 9d exerted 44,81,81, 60 and $84 \%$ growth inhibition against the leukemia cell lines CCRF-CEM, HL-60, K-562, MOLT-4 and SR, respectively; 45, 53, and 64\% of inhibition against non-small cell lung cancer cell lines HOP-92, NCI-H460, NCI-H522, respectively; 49, 62, 59, 56, and 60\% of inhibition against HCT-116, HCT-15, HT29, KM12, and SW-620, respectively from colon cancer; 54 and 44\% against SF-295 and U251 from CNS cancer; 50\%, lethal effect, 45, and 63\% of inhibition against M14, MDA-MB-435, SK-MEL-5, UACC-62, respectively from melanoma cell lines; 46 and 55\% against OVCAR-3 and NCI/ADR-RES, respectively from ovarian cancer cell lines; 41 and $52 \%$ of inhibition against A498 and CAKI-1, respectively from renal cancer; $43 \%$ of inhibition against PC-3 from prostate cancer and $42 \%$ of inhibition against MCF7 cell line from breast cancer. Compound $\mathbf{6} f$ is the second most potent compound with mean growth inhibition percentage of $18 \%, \mathbf{6 f}$ exerted $40,46,44$, and $49 \%$ growth inhibition against IGROV1, A498, MCF-7, and T-47D cell line, respectively.

\subsubsection{Estimation of physicochemical, pharmacokinetic, and ADME properties}

Estimation of the physicochemical and pharmacokinetic properties, as well as ADME parameters of the synthesized imidazopyrimidines, was carried out using SwissADME free web tool [33]. Selected results were depicted in Table 5. Analysis of the obtained results revealed that the synthesized imidazopyrimidines 6a-u and 9a-d have acceptable physicochemical properties such as molecular weights between $356-483 \mathrm{~g} / \mathrm{mol}$, topological polar surface areas (TPSA) ranging from 96.74 to $134.87 \AA$, iLOGP (octanol-water partition coefficient)[34] between 2.22-3.15 and acceptable number of hydrogen bond donors and acceptors.

The imidazopyrimidines have moderate water solubility and all of them are predicted to be well absorbed from GIT. With the exception of compounds 6a-e, $6 \mathbf{h}$ and 9a-d the rest of compounds do not have the probability to penetrate $\mathrm{BBB}$, therefore, no side effects are expected to occur in the CNS. Moreover, most of the examined compounds are non-substrates for the most important 
efflux transporter P-glycoprotein (P-gp) which exerts a predominate role in pumping xenobiotic outside the cells. Hence, the imidazopyrimidines are expected to be well absorbed and controlled excreted from the site of action.

Bioavailability radar provided from SwissADME web tool [33] showed that most of the tested compounds exhibited promising predicted physicochemical properties for oral bioavailability. For instance, figure 5 displays the bioavailability radar chart of compounds $6 \mathbf{6 f}, \mathbf{6 g}$ and $9 \mathbf{d}$ (For the bioavailability radar for the rest of compounds, check supporting information). The ideal space of six physicochemical parameters e.g. size, polarity, lipophilicity, solubility, flexibility, and saturation for oral bioavailability are located in pink colored area [33]. All the synthesized imidazopyrimidines are almost present in the pink area, the fraction of $\mathrm{sp}^{3}$ hybridized carbons are less than 0.25 in some cases, hence it is deviated out from the pink zone. It was curious to mention that none of 6a-u and 9a-d violated the drug- likeness rules including Lipinski's rule [35], Veber rule [36], Ghose-filter [37], Egan [38], and Muegge's [39] filter and they do not exhibit any of Pan Assay Interference (PAINS) sub compounds [40].

Table 5. Selected calculated physicochemical and pharmacokinetic properties of 6a-u and 9a-d from swissADME free web tool.

\begin{tabular}{lllllllllll}
\hline Product & MW & Rotatable & H-bond & H-bond & MR & TPSA & Log P & $\begin{array}{l}\text { GI } \\
\text { absorption }\end{array}$ & $\begin{array}{l}\text { BBB } \\
\text { permeant }\end{array}$ & $\begin{array}{l}\text { Pgp } \\
\text { substrate }\end{array}$ \\
& & bonds & Acc. & Don. & & & & & & \\
\hline 6a & 312.32 & 2 & 3 & 1 & 91.4 & 73.95 & 2.51 & High & Yes & No \\
6b & 330.32 & 2 & 4 & 1 & 91.36 & 73.95 & 2.56 & High & Yes & No \\
6c & 346.77 & 2 & 3 & 1 & 96.41 & 73.95 & 2.72 & High & Yes & No \\
6d & 391.22 & 2 & 3 & 1 & 99.1 & 73.95 & 2.84 & High & Yes & No \\
6e & 326.35 & 2 & 3 & 1 & 96.37 & 73.95 & 2.79 & High & Yes & No \\
6f & 342.35 & 3 & 4 & 1 & 97.89 & 83.18 & 2.9 & High & No & No \\
6g & 381.21 & 2 & 3 & 1 & 101.42 & 73.95 & 2.88 & High & No & No \\
6h & 362.38 & 2 & 3 & 1 & 108.91 & 73.95 & 2.91 & High & Yes & Yes \\
6i & 360.34 & 3 & 5 & 1 & 97.85 & 83.18 & 2.95 & High & No & No
\end{tabular}




\begin{tabular}{|c|c|c|c|c|c|c|c|c|c|c|}
\hline $6 \mathbf{j}$ & 376.8 & 3 & 4 & 1 & 102.9 & 83.18 & 3.07 & High & No & No \\
\hline $6 k$ & 372.38 & 4 & 5 & 1 & 104.38 & 92.41 & 3.1 & High & No & No \\
\hline 61 & 390.37 & 4 & 6 & 1 & 104.34 & 92.41 & 3.13 & High & No & No \\
\hline $6 \mathrm{~m}$ & 406.82 & 4 & 5 & 1 & 109.39 & 92.41 & 3.32 & High & No & No \\
\hline $6 n$ & 402.4 & 5 & 6 & 1 & 110.88 & 101.64 & 3.31 & High & No & Yes \\
\hline 60 & 402.4 & 5 & 6 & 1 & 110.88 & 101.64 & 3.19 & High & No & Yes \\
\hline $6 p$ & 436.85 & 5 & 6 & 1 & 115.89 & 101.64 & 3.41 & High & No & No \\
\hline $6 q$ & 481.3 & 5 & 6 & 1 & 118.58 & 101.64 & 3.56 & High & No & No \\
\hline $6 r$ & 416.43 & 5 & 6 & 1 & 115.84 & 101.64 & 3.43 & High & No & Yes \\
\hline $6 s$ & 432.43 & 6 & 7 & 1 & 117.37 & 110.87 & 3.63 & High & No & Yes \\
\hline $6 t$ & 471.29 & 5 & 6 & 1 & 120.9 & 101.64 & 3.49 & High & No & No \\
\hline $6 u$ & 452.46 & 5 & 6 & 1 & 128.38 & 101.64 & 3.53 & High & No & Yes \\
\hline $9 a$ & 259.69 & 1 & 2 & 1 & 71.22 & 50.16 & 2.43 & High & Yes & No \\
\hline $9 \mathrm{~b}$ & 257.26 & 2 & 3 & 1 & 70.98 & 50.16 & 2.53 & High & Yes & No \\
\hline $9 \mathrm{c}$ & 273.72 & 2 & 2 & 1 & 76.03 & 50.16 & 2.7 & High & Yes & No \\
\hline 9d & 305.31 & 2 & 3 & 1 & 86.64 & 50.16 & 2.76 & High & Yes & No \\
\hline
\end{tabular}

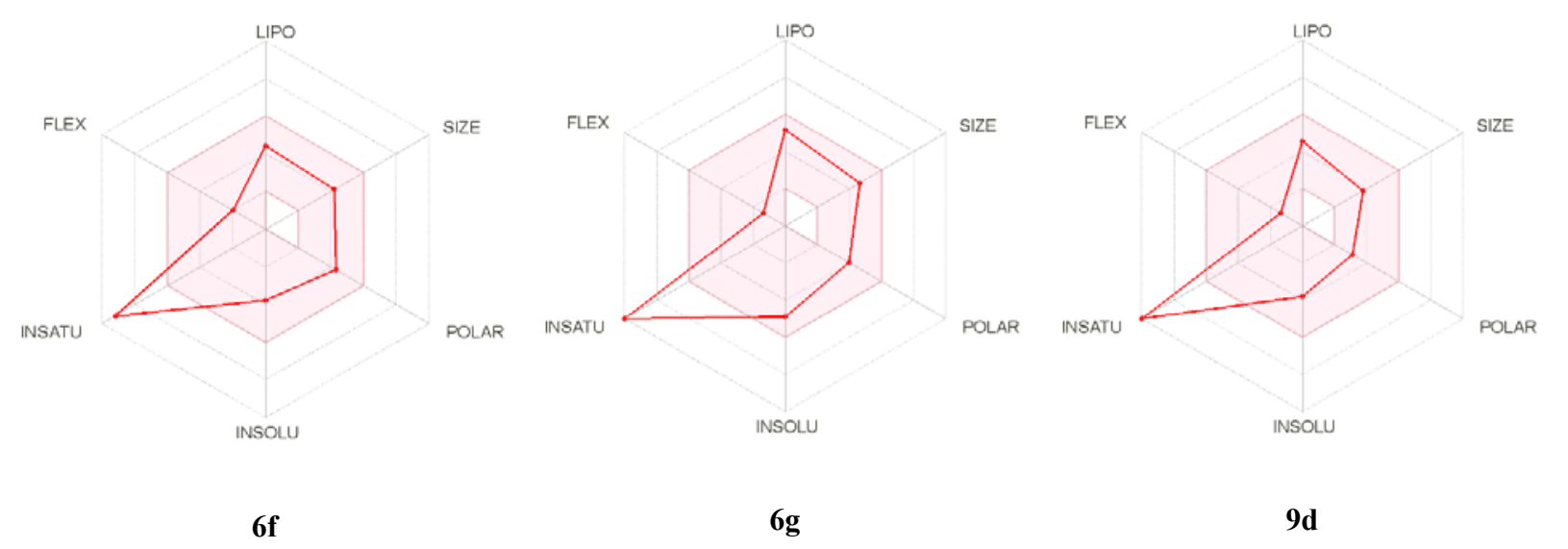

Figure 5. Bioavailability radar plot from swissADME online web tool for $\mathbf{6 f}, \mathbf{6 g}$ and $\mathbf{9 d}$.

From results of ADME prediction study, it was interesting to summarize that the synthesized imidazopyrimidines are not only of promising chemotherapeutic properties but also satisfy the 
essential physicochemical, pharmacokinetic and drug likeness parameters for future discovery of chemotherapeutic agents.

\section{CONCLUSION}

In summary, we have presented a simple and efficient method for the synthesis of a new series of imidazopyrimidines 6 and 9 by a domino reaction between 2-imino-4-oxo-6-substituted-1,2,3,4tetrahydropyrimidines $\mathbf{4}$ or $\mathbf{8}$ and 2-bromoacetophenone $\mathbf{5}$. The newly synthesized compounds $\mathbf{6}$ and 9 showed promising activity against Gram (-) bacteria over Gram (+) ones. Generally, compounds exhibiting a phenyl group at the seven position 6a-g demonstrated promising antibacterial activity over compounds having methoxyphenyl groups $\mathbf{6 i - u}$. Compounds $\mathbf{6 c}, \mathbf{6} \mathbf{f}$ and 6g showed potent and broad-spectrum of antibacterial activity over the tested microorganism. Both $\mathbf{6 c}$ and $\mathbf{6 g}$ with chlorophenyl groups at the two position showed MIC of 10.0 and 12.5 $\mu \mathrm{g} / \mathrm{mL}$ against $E$. coli and $S$. typhi, respectively, whereas, compound $6 \mathbf{f}$ with 2-methoxyphenyl group at the two position displayed MIC of $12.5,12.5$ and $25 \mu \mathrm{g} / \mathrm{mL}$ against E. coli, $P$. aeruginosa and $S$. typhi, respectively. In addition, $6 \mathbf{f}$ and $\mathbf{6 g}$ displayed $\mathrm{IC}_{50}$ of 1.14 and $0.73 \mu \mathrm{M}$ in GyrB ATPase assay. The synthesized compounds revealed promising antiproliferative activity against NCI cancer cell lines. Compound 9d showed broad spectrum of cytotoxic activity between $10 \%$ to lethal effect against the tested cell lines. In silico prediction of physicochemical and pharmacokinetic properties of the new imidazopyrimidines showed that they are promising candidates to be further optimized for the discovery of oral chemotherapeutic agents.

\section{EXPERIMENTAL}

\subsection{Chemistry}

\section{General remarks}

All chemicals were purchased from commercial suppliers. Analytical thin layer chromatography (TLC) was performed on precoated silica gel $60 \mathrm{~F}_{245}$ aluminium plates (Merck) with visualization under UV light. Melting points were determined on a Stuart SMP30 melting point apparatus with open capillary tubes and are uncorrected. Elemental analysis and spectral data of the compounds were performed in the Micro analytical labs, National Research Centre, Cairo, Egypt. IR spectra (4000-400 $\mathrm{cm}^{-1}$ ) were recorded using $\mathrm{KBr}$ pellets in a Jasco FT/IR 6100E Fourier transform 
infrared spectrophotometer. ${ }^{1} \mathrm{H}$ NMR and ${ }^{13} \mathrm{C}$ NMR spectra were recorded at 400 (100) $\mathrm{MHz}$ and 300 (75) MHz on Bruker, Agilent and a Varian Unity Inova instruments, respectively using DMSO$d_{6}$ as a solvent. Chemical shifts are given in parts per million ( $\mathrm{ppm}$ ) relative to TMS as internal standards. Coupling constants are reported in Hertz (Hz).

Synthesis of 4a-d and 8a-c

The starting 2-imino-4-oxo-6-substituted-1,2,3,4-tetrahydropyrimidine-5-carbonitriles 4 and 2imino-6-substituted-2,3-dihydropyrimidin-4(1H)-ones $\mathbf{8}$ were synthesized according to the previously reported procedure [28].

General procedure for the synthesis of $\mathbf{6 a - u}$ and $\mathbf{9 a - d}$

A mixture of $\mathbf{4}$ or $\mathbf{8}, 2$-bromoacetophenones $\mathbf{5}$ and $\mathrm{NaHCO}_{3}$ was stirred in ethanol under reflux for $4 \mathrm{~h}$. The reaction mixture was then cooled to room temperature followed by filtration and the filter was washed with ethanol. The filtrate was concentrated to one third its original volume and poured on to ice/water and neutralized with $2 \mathrm{~N} \mathrm{HCl}$. The precipitated product was filtered and dried to give the crude product which was further purified by crystallization from methanol or by column chromatography to give analytically pure products.

5-Oxo-2,7-diphenyl-1,5-dihydroimidazo[1,2-a]pyrimidine-6-carbonitrile (6a)

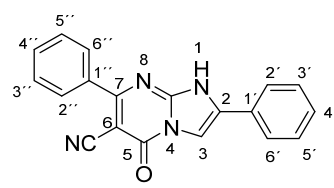

White powder; yield: $56 \%$; mp $>300{ }^{\circ} \mathrm{C} ;{ }^{1} \mathrm{H}$ NMR (400 MHz; DMSO- $\left.d 6\right)$ 7.42-7.46 (1H, m, H$\left.4^{\prime \prime}\right)$, 7.49-7.53 (2H, m, H-3"', H-5' ), 7.55-7.57 (3H, m, H-3', H-4', H-5'), 7.86-7.88 (2H, m, H$2^{\prime \prime}$, H-6" or H-2', H-6'), 8.00 (2H, d, ${ }^{3} J=7.2 \mathrm{~Hz}, \mathrm{H}-2^{\prime \prime}$, H-6" or H-2', H-6'), 8.42 ppm (1H, s, $\mathrm{H}-3) ;{ }^{13} \mathrm{C}$ NMR (100 MHz; DMSO-d6) 82.91, 104.55, 117.50, 125.47, 127.04, 128.39, 128.50, 129.16, 129.50, 130.69, 131.58, 136.84, 147.14, 156.53, $166.52 \mathrm{ppm}$; Anal. Calcd for $\mathrm{C}_{19} \mathrm{H}_{12} \mathrm{~N}_{4} \mathrm{O}: \mathrm{C}, 73.07 ; \mathrm{H}, 3.87 ; \mathrm{N}, 17.94$. Found: $\mathrm{C}, 73.35 ; \mathrm{H}, 3.48 ; \mathrm{N}, 17.63$.

2-(4-Fluorophenyl)-5-oxo-7-phenyl-1,5-dihydroimidazo[1,2-a]pyrimidine-6-carbonitrile (6b) 


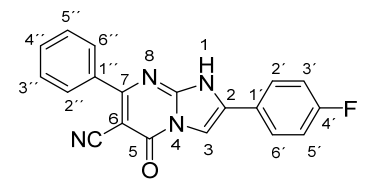

White powder; yield: $54 \%$; mp > $300{ }^{\circ} \mathrm{C}$; ${ }^{1} \mathrm{H}$ NMR (400 MHz; DMSO- $\left.d_{6}\right) 7.38\left(2 \mathrm{H}, \mathrm{t},{ }^{3} J=8.8\right.$ Hz, H-3', H-5'), 7.56-7.57 (3H, m, H-3' ', H-4' ', H-5' '), 7.86-7.88 (2H, m, H-2', H-6'), 8.00-8.03 (2H, m, H-2"' H-6" '), 8.43 (1H, s, H-3), 14.27 ppm (1H, br., $\mathrm{NH})$; Anal. Calcd for $\mathrm{C}_{19} \mathrm{H}_{11} \mathrm{FN}_{4} \mathrm{O}$ : C, 69.09; H, 3.36; N, 16.96. Found: C, 69.39; H, 3.12; N, 16.60.

2-(4-Chlorophenyl)-5-oxo-7-phenyl-1,5-dihydroimidazo[1,2-a]pyrimidine-6-carbonitrile (6c)

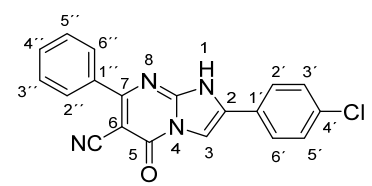

White powder; yield: $50 \%$; $\mathrm{mp}>300{ }^{\circ} \mathrm{C}$; $v$ max (atr)/ $\mathrm{cm}^{-1} 3137,2214,1654,1578$ and $1484 ;{ }^{1} \mathrm{H}$ NMR (400 MHz; DMSO-d6) 7.56-7.59 (5H, m, H-2"', H-3"', H-4"', H-5"', H-6"'), 7.86 (2H, d, ${ }^{3} J$ $\left.=6.8 \mathrm{~Hz}, \mathrm{H}-2^{\prime}, \mathrm{H}-6^{\prime}\right), 7.98\left(2 \mathrm{H}, \mathrm{d},{ }^{3} J=6.8 \mathrm{~Hz}, \mathrm{H}-3^{\prime}, \mathrm{H}-5^{\prime}\right), 8.47 \mathrm{ppm}(1 \mathrm{H}, \mathrm{s}, \mathrm{H}-3) ;{ }^{13} \mathrm{C} \mathrm{NMR}$ (100 MHz; DMSO-d6) 82.14, 105.02, 113.23, 117.65, 127.22, 128.20, 128.38, 128.49, 129.20, 130.63, 133.89, 135.38, 147.45, 154.46, 166.60 ppm; Anal. Calcd for $\mathrm{C}_{19} \mathrm{H}_{11} \mathrm{ClN}_{4} \mathrm{O}: \mathrm{C}, 65.81$; $\mathrm{H}$, $3.20 ; \mathrm{N}, 16.16$. Found: C, 65.58; H, 3.55; N, 16.03.

2-(4-Bromophenyl)-5-oxo-7-phenyl-1,5-dihydroimidazo[1,2-a]pyrimidine-6-carbonitrile (6d)

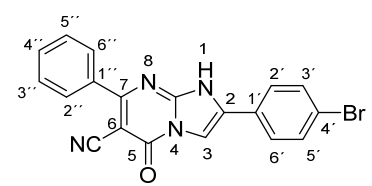

White powder; yield: $56 \%$; $\mathrm{mp}>300{ }^{\circ} \mathrm{C}$; $v$ max (atr)/ $\mathrm{cm}^{-1} 3200,3056,2220,1652,1575$ and 1482; ${ }^{1} \mathrm{H}$ NMR (400 MHz; DMSO-d6) 7.49-7.57 (3H, m, H-3"', H-4"', H-5' ), 7.72 (2H, d, ${ }^{3} J=$ 7.5 Hz, H-2', H-6'), 7.85-7.86 (2H, m, H-2'', H-6' '), 7.92 (2H, d, ${ }^{3} J=7.6$ Hz, H-3', H-5'), 8.49 ppm (1H, s, H-3); ${ }^{13} \mathrm{C}$ NMR (100 MHz; DMSO-d6) 82.71, 105.14, 113.33, 117.50, 122.66, $127.45,128.40,128.49$, 130.69, 131.01, 132.13, 135.41, 147.16, 156.59, 165.45 ppm; Anal. Calcd for $\mathrm{C}_{19} \mathrm{H}_{11} \mathrm{BrN}_{4} \mathrm{O}: \mathrm{C}, 58.33 ; \mathrm{H}, 2.83 ; \mathrm{N}, 14.32$. Found: C, 58.71; H, 2.53; N, 14.64. 
5-Oxo-7-phenyl-2-(p-tolyl)-1,5-dihydroimidazo[1,2-a]pyrimidine-6-carbonitrile (6e)

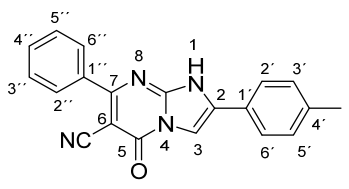

White powder; yield: $39 \%$; $\mathrm{mp}>300{ }^{\circ} \mathrm{C}$; $v$ max (atr) $/ \mathrm{cm}^{-1} 3300,3118,2217,1646,1562$ and 1480; ${ }^{1} \mathrm{H}$ NMR (400 MHz; DMSO-d6) $2.32\left(3 \mathrm{H}, \mathrm{s}, \mathrm{CH}_{3}\right), 7.27$ (2H, d, ${ }^{3} J=7.8 \mathrm{~Hz}, \mathrm{H}-3$ ', H-5'), 7.54-7.55 (3H, m, H-3"', H-4"', H-5' ), 7.79 (2H, d ${ }^{3} J=7.8 \mathrm{~Hz}, \mathrm{H}-2^{\prime}, \mathrm{H}-6$ '), $7.84\left(2 \mathrm{H}, \mathrm{d},{ }^{3} J=7.1\right.$ Hz, H-2", H-6" ), 8.27 ppm (1H, s, H-3); ${ }^{13} \mathrm{C}$ NMR (100 MHz; DMSO-d6) 20.91, 82.72, 103.89, $117.59,124.36,125.42,128.38,128.49,129.70,130.63,131.88,136.93,139.23,147.13,156.57$, 166.30 ppm; Anal. Calcd for $\mathrm{C}_{20} \mathrm{H}_{14} \mathrm{~N}_{4} \mathrm{O}$ : C, 73.61; H, 4.32; N, 17.17. Found: C, 73.37; H, 4.11; N, 17.45 .

2-(2-Methoxyphenyl)-5-oxo-7-phenyl-1,5-dihydroimidazo[1,2-a]pyrimidine-6-carbonitrile (6f)

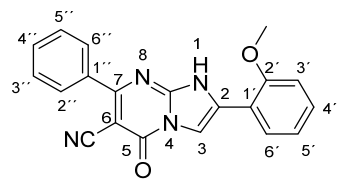

White powder; yield: $66 \%$; mp > $300{ }^{\circ} \mathrm{C}$; ${ }^{1} \mathrm{H}$ NMR (400 MHz; DMSO- $\left.d_{6}\right) 3.99\left(3 \mathrm{H}, \mathrm{s}, \mathrm{OCH}_{3}\right)$, $7.11\left(1 \mathrm{H}, \mathrm{t},{ }^{3} J=7.6 \mathrm{~Hz}, \mathrm{H}-5^{\prime}\right), 7.28\left(1 \mathrm{H}, \mathrm{d},{ }^{3} J=8.4 \mathrm{~Hz}, \mathrm{H}-3^{\prime}\right), 7.46\left(1 \mathrm{H}, \mathrm{t},{ }^{3} J=8.4 \mathrm{~Hz}, \mathrm{H}-4^{\prime}\right)$, 7.55-7.57 (3H, m, H-3"', H-4"', H-5' ), 7.85-7.89 (3H, m, H-2"', H-6"', H-6'), 8.02 ppm (1H, s, H-3); ${ }^{13} \mathrm{C}$ NMR (100 MHz; DMSO-d6) 55.82, 82.77, 106.42, 111.99, 115.17, 117.53, 120.83, 127.24, 128.37, 128.52, 129.63, 130.66, 130.87, 136.89, 146.47, 156.50, 156.53, 166.58 ppm; Anal. Calcd for $\mathrm{C}_{20} \mathrm{H}_{14} \mathrm{~N}_{4} \mathrm{O}_{2}$ : C, 70.17; H, 4.12; N, 16.37. Found: C, 70.38; H, 4.45; N, 16.08.

2-(3,4-Dichlorophenyl)-5-oxo-7-phenyl-1,5-dihydroimidazo[1,2-a]pyrimidine-6-carbonitrile (6g)

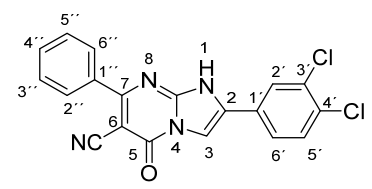

White powder; yield: $39 \%$; $\mathrm{mp}>300{ }^{\circ} \mathrm{C}$; $v$ max (atr)/ $\mathrm{cm}^{-1} 3400,3122,2213,1692,1589$ and 1491; ${ }^{1} \mathrm{H}$ NMR (400 MHz; DMSO-d6) 7.55-7.57 (3H, m, H-3"', H-4"', H-5' ), 7.77 (1H, d, ${ }^{3} J=$ 8.4 Hz, H-5'), 7.84-7.87 (2H, m, H-2'", H-6"' $), 7.93$ (1H, dd, $\left.{ }^{3} J=8.4 \mathrm{~Hz}, \mathrm{~d},{ }^{4} J=2.0 \mathrm{~Hz}, \mathrm{H}-6^{\prime}\right)$, 
$8.27\left(1 \mathrm{H}, \mathrm{d},{ }^{4} \mathrm{~J}=2.0 \mathrm{~Hz}, \mathrm{H}-2{ }^{\prime}\right), 8.58 \mathrm{ppm}(1 \mathrm{H}, \mathrm{s}, \mathrm{H}-3) ;{ }^{13} \mathrm{C}$ NMR (100 MHz; DMSO-d6) 82.61, $106.14,117.45,125.50,127.26,128.24,128.45,128.53,128.65,130.80,131.39,131.78,132.15$, 136.65, 147.23, 156.56, 166.44 ppm; Anal. Calcd for $\mathrm{C}_{19} \mathrm{H}_{10} \mathrm{Cl}_{2} \mathrm{~N}_{4} \mathrm{O}: \mathrm{C}, 59.86 ; \mathrm{H}, 2.64 ; \mathrm{N}, 14.70$. Found: C, 59.54; H, 2.33; N, 14.92.

2-(Naphthalen-2-yl)-5-oxo-7-phenyl-1,5-dihydroimidazo[1,2-a]pyrimidine-6-carbonitrile (6h)

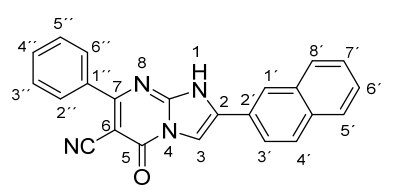

White powder; yield: $75 \%$; mp $>300{ }^{\circ} \mathrm{C} ;{ }^{1} \mathrm{H}$ NMR (400 MHz; DMSO- $\left.d 6\right)$ 7.57-7.59 (5H, m, H2"', H-3"', H-4"', H-5'", H-6' '), 7.87-7.96 (4H, m, H-5', H-6', H-7', H-8'), 8.03 (1H, d, ${ }^{3} J=8.4$ $\left.\mathrm{Hz}, \mathrm{H}-4^{\prime}\right), 8.09\left(1 \mathrm{H}, \mathrm{dd},{ }^{3} J=8.8 \mathrm{~Hz},{ }^{4} J=1.6 \mathrm{~Hz}, \mathrm{H}-3^{\prime}\right), 8.50(1 \mathrm{H}, \mathrm{s}, \mathrm{H}-3$ or H-1'), $8.52 \mathrm{ppm}(1 \mathrm{H}$, s, H-3 or H-1'); ${ }^{13} \mathrm{C}$ NMR (100 MHz; DMSO-d6) 82.89, 105.07, 117.52, 123.05, 124.51, 124.57, $127.09,127.11,127.78,128.15,128.40,128.51,128.84,130.69,131.76,132.70,132.98,136.86$, 147.25, 156.54, 166.48 ppm; Anal. Calcd for $\mathrm{C}_{23} \mathrm{H}_{14} \mathrm{~N}_{4} \mathrm{O}$ : C, 76.23; H, 3.89; N, 15.46. Found: C, $76.53 ; \mathrm{H}, 3.65 ; \mathrm{N}, 15.78$.

2-(4-Fluorophenyl)-7-(4-methoxyphenyl)-5-oxo-1,5-dihydroimidazo[1,2-a]pyrimidine-6carbonitrile (6i)

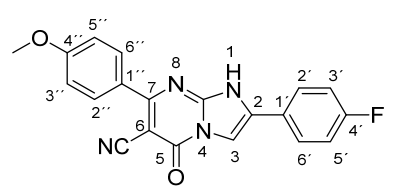

Pale yellow powder; yield: $43 \%$; $\mathrm{mp}>300{ }^{\circ} \mathrm{C} ; \dot{v} \max \left(\right.$ atr) $/ \mathrm{cm}^{-1} 3379,3145,3005,2218,1678$, 1566 and 1489; ${ }^{1} \mathrm{H}$ NMR (400 MHz; DMSO-d6) $3.80\left(3 \mathrm{H}, \mathrm{s}, \mathrm{OCH}_{3}\right), 7.03\left(2 \mathrm{H}, \mathrm{d},{ }^{3} J=8.8 \mathrm{~Hz}, \mathrm{H}-\right.$ $\left.3^{\prime \prime}, \mathrm{H}-5^{\prime \prime}\right), 7.60$ (2H, dd, $\left.J=8.4 \mathrm{~Hz}, J=5.6 \mathrm{~Hz}, \mathrm{H}-33^{\prime}, \mathrm{H}-5^{\prime}\right), 7.86$ (2H, d, $J=9.0 \mathrm{~Hz}, \mathrm{H}-2^{\prime \prime}, \mathrm{H}-$ $\left.6^{\prime \prime}\right), 8.13\left(2 \mathrm{H}, \mathrm{dd}, J=8.8 \mathrm{~Hz}, J=5.6 \mathrm{~Hz}, \mathrm{H}-2^{\prime}, \mathrm{H}-6^{\prime}\right), 8.18 \mathrm{ppm}(1 \mathrm{H}, \mathrm{s}, \mathrm{H}-3)$; Anal. Calcd for $\mathrm{C}_{20} \mathrm{H}_{13} \mathrm{FN}_{4} \mathrm{O}_{2}$ : C, 66.66; H, 3.64; N, 15.55. Found: C, C, 66.42; H, 3.43; N, 15.87.

2-(4-Chlorophenyl)-7-(4-methoxyphenyl)-5-oxo-1,5-dihydroimidazo[1,2-a]pyrimidine-6carbonitrile $(6 \mathbf{j})$ 


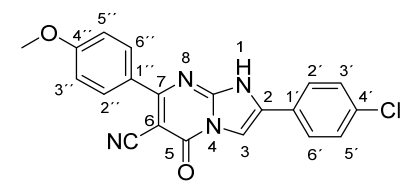

Pale yellow powder; yield: 42\%; mp > $300{ }^{\circ} \mathrm{C}$; ${ }^{1} \mathrm{H}$ NMR (400 MHz; DMSO-d6) $3.83(3 \mathrm{H}$, s, $\left.\mathrm{OCH}_{3}\right), 7.09$ (2H, d, $\left.{ }^{3} \mathrm{~J}=8.8 \mathrm{~Hz}, \mathrm{H}-3^{\prime \prime}, \mathrm{H}-5^{\prime \prime}\right), 7.54\left(2 \mathrm{H}, \mathrm{d},{ }^{3} \mathrm{~J}=8.4 \mathrm{~Hz}, \mathrm{H}-2^{\prime}, \mathrm{H}-6{ }^{\prime}\right), 7.87$ (2H, d, ${ }^{3} J=8.4 \mathrm{~Hz}, \mathrm{H}-2^{\prime \prime}$, H-6" ) 7.92 (2H, d, ${ }^{3} J=8.4 \mathrm{~Hz}, \mathrm{H}-3$ ', H-5'), 8.37 ppm (1H, s, H-3); ${ }^{13} \mathrm{C}$ NMR (100 MHz; DMSO-d6) 55.42, 82.73, 99.59, 111.12, 113.81, 114.69, 127.18, 128.80, 129.23, 130.17, 130.32, 130.79, 134.00, 147.01, 159.63, 161.32 ppm; Anal. Calcd for $\mathrm{C}_{20} \mathrm{H}_{13} \mathrm{ClN}_{4} \mathrm{O}_{2}$ : $\mathrm{C}$, $63.75 ; \mathrm{H}, 3.48$; N, 14.87. Found: C, 63.48; H, 3.75; N, 14.51.

2,7-Bis(4-methoxyphenyl)-5-oxo-1,5-dihydroimidazo[1,2-a]pyrimidine-6-carbonitrile (6k)

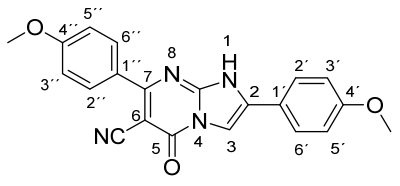

Pale yellow powder; yield: $33 \%$; mp $>300{ }^{\circ} \mathrm{C}$; ${ }^{1} \mathrm{H}$ NMR (400 MHz; DMSO-d6) $3.80(3 \mathrm{H}, \mathrm{s}$, $\left.\mathrm{OCH}_{3}\right), 3.84\left(3 \mathrm{H}, \mathrm{s}, \mathrm{OCH}_{3}\right), 7.05\left(2 \mathrm{H}, \mathrm{d},{ }^{3} \mathrm{~J}=8.8 \mathrm{~Hz}, \mathrm{H}-3^{\prime \prime}, \mathrm{H}-5^{\prime \prime}\right), 7.10\left(2 \mathrm{H}, \mathrm{d},{ }^{3} \mathrm{~J}=8.8 \mathrm{~Hz}, \mathrm{H}-\right.$ $3^{\prime}$, H-5'), 7.88 (2H, ov. d like, ${ }^{3} J=8.8 \mathrm{~Hz}, \mathrm{H}-2^{\prime \prime}, \mathrm{H}-6^{\prime \prime}$ or H-2', H-6'), 7.89 (2H, ov. d like, ${ }^{3} J=$ $8.4 \mathrm{~Hz}, \mathrm{H}-2^{\prime \prime}, \mathrm{H}-6$ "' or H-2', H-6' $), 8.24$ (1H, s, H-3), 13.93 ppm (1H, br., NH); ${ }^{13} \mathrm{C}$ NMR (100 MHz; DMSO- $\left.d_{6}\right)$ 55.80, 56.01, 82.65, 106.27, 111.95, 117.72, 120.81, 125.40, 127.17, 130.85, 131.31, 132.10, 139.52, 146.18, 155.48, 156.52, 165.94 ppm; Anal. Calcd for $\mathrm{C}_{21} \mathrm{H}_{16} \mathrm{~N}_{4} \mathrm{O}_{3}$ : C, 67.73; H, 4.33; N, 15.05. Found: C, 67.43; H, 4.65; N, 15.35 .

7-(2,5-Dimethoxyphenyl)-2-(4-fluorophenyl)-5-oxo-1,5-dihydroimidazo[1,2-a]pyrimidine-6carbonitrile (61)

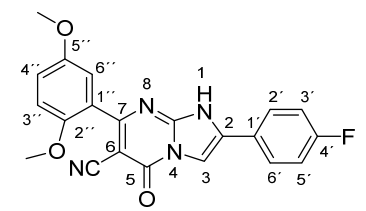

Pale yellow powder; yield: $25 \%$; mp $>300{ }^{\circ} \mathrm{C}$; ${ }^{1} \mathrm{H}$ NMR (400 MHz; DMSO-d6) $3.74(3 \mathrm{H}$, s, $\left.\mathrm{OCH}_{3}\right), 3.77\left(3 \mathrm{H}, \mathrm{s}, \mathrm{OCH}_{3}\right), 6.98\left(1 \mathrm{H}, \mathrm{d},{ }^{3} J=3.2 \mathrm{~Hz}, \mathrm{H}-6{ }^{\prime \prime}\right), 7.07\left(1 \mathrm{H}, \mathrm{dd},{ }^{3} J=8.8 \mathrm{~Hz},{ }^{4} J=3.2\right.$ $\left.\mathrm{Hz}, \mathrm{H}-4^{\prime \prime}\right), 7.12$ (1H, d, $\left.{ }^{3} J=9.0 \mathrm{~Hz}, \mathrm{H}-3^{\prime \prime}\right), 7.37$ (2H, t, $\left.{ }^{3} J=8.8 \mathrm{~Hz}, \mathrm{H}-3{ }^{\prime}, \mathrm{H}-55^{\prime}\right), 7.99-8.02$ (2H, m, H-2', H-6'), 8.43 (1H, s, H-3), 14.26 ppm (1H, br., NH); ${ }^{13} \mathrm{C}$ NMR (100 MHz; DMSO-d6) 
$55.64,55.97,85.83,104.55,113.17,115.05,116.33(\mathrm{~d}, J=21.8 \mathrm{~Hz}), 116.76(\mathrm{~d}, J=21.2 \mathrm{~Hz})$, 124.06, 126.83, 127.98 (d, $J=8.6 \mathrm{~Hz}), 131.36,147.12,150.42,152.86,154.23,155.89,162.69$ $(\mathrm{d}, J=245.6 \mathrm{~Hz}), 165.15 \mathrm{ppm}$; Anal. Calcd for $\mathrm{C}_{21} \mathrm{H}_{15} \mathrm{FN}_{4} \mathrm{O}_{3}$ : C, 64.61; H, 3.87; N, 14.35. Found: C, 64.92; H, 3.65; N, 14.68 .

2-(4-Chlorophenyl)-7-(2,5-dimethoxyphenyl)-5-oxo-1,5-dihydroimidazo[1,2-a]pyrimidine-6carbonitrile $(6 \mathrm{~m})$

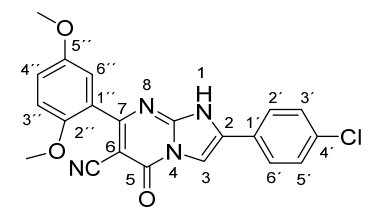

Pale yellow powder; yield: $46 \%$; $\mathrm{mp}>300{ }^{\circ} \mathrm{C}$; $v$ max (atr)/ $/ \mathrm{cm}^{-1} 3475,3136,3044,2222,1663$, 1578 and 1489; ${ }^{1} \mathrm{H}$ NMR (400 MHz; DMSO-d $) 3.74\left(3 \mathrm{H}, \mathrm{s}, \mathrm{OCH}_{3}\right), 3.77\left(3 \mathrm{H}, \mathrm{s}, \mathrm{OCH}_{3}\right), 6.98$ $\left(1 \mathrm{H}, \mathrm{d},{ }^{4} J=3.2 \mathrm{~Hz}, \mathrm{H}-6^{\prime \prime}\right), 7.07\left(1 \mathrm{H}, \mathrm{d},{ }^{3} J=9.2 \mathrm{~Hz},{ }^{4} J=3.2 \mathrm{~Hz}, \mathrm{H}-4^{\prime \prime}\right), 7.12\left(1 \mathrm{H}, \mathrm{d},{ }^{3} J=9.2 \mathrm{~Hz}\right.$, H-3' ) 7.58 (2H, d, ${ }^{3} J=8.4$ Hz, H-2', H-6'), 7.97 (2H, d, ${ }^{3} J=8.4$ Hz, H-3', H-5'), 8.48 (1H, s, H-3), 14.24 ppm (1H, br., NH); ${ }^{13} \mathrm{C}$ NMR (100 MHz; DMSO-d6) 55.58, 55.91, 82.41, 105.13, 113.10, 114.98, 115.88, 116.57, 116.81, 127.28, 129.21, 129.65, 133.95, 147.15, 150.36, 152.78, 155.84, 156.60, 164.50 ppm; Anal. Calcd for $\mathrm{C}_{21} \mathrm{H}_{15} \mathrm{ClN}_{4} \mathrm{O}_{3}$ : C, 62.00; H, 3.72; N, 13.77. Found: C, 62.32; H, 3.93; N, 13.90 .

7-(2,5-Dimethoxyphenyl)-2-(4-methoxyphenyl)-5-oxo-1,5-dihydroimidazo[1,2-a]pyrimidine-6carbonitrile (6n)

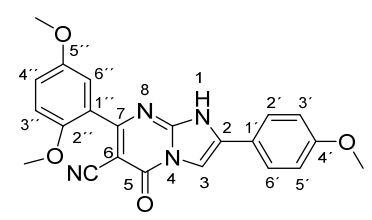

Pale yellow powder; yield: $37 \%$; mp $>300{ }^{\circ} \mathrm{C}$; ${ }^{1} \mathrm{H}$ NMR (400 MHz; DMSO-d6) $3.74(3 \mathrm{H}, \mathrm{s}$, $\left.\mathrm{OCH}_{3}\right), 3.77\left(3 \mathrm{H}, \mathrm{s}, \mathrm{OCH}_{3}\right), 3.81\left(3 \mathrm{H}, \mathrm{s}, \mathrm{OCH}_{3}\right), 6.98\left(1 \mathrm{H}, \mathrm{d},{ }^{3} \mathrm{~J}=2.8 \mathrm{~Hz}, \mathrm{H}-6{ }^{\prime \prime}\right), 7.06-7.08$ (3H, m, H-4' , H-3', H-5'), 7.12 (1H, d, $\left.{ }^{3} J=9.1 \mathrm{~Hz}, \mathrm{H}-3^{\prime \prime}\right), 7.89$ (2H, d, $\left.{ }^{3} J=8.8 \mathrm{~Hz}, \mathrm{H}-2^{\prime}, \mathrm{H}-6^{\prime}\right), 8.30$ $(1 \mathrm{H}, \mathrm{s}, \mathrm{H}-3), 14.12$ ppm (1H, br., NH); ${ }^{13} \mathrm{C}$ NMR (100 MHz; DMSO-d6) 55.47, 55.98, 56.02, $82.09,106.14,113.17,115.21,116.02,116.21,116.36,116.43,122.31,126.79,131.59,132.99$, 
146.33, 150.27, 152.75, 155.35, 165.73 ppm; Anal. Calcd for $\mathrm{C}_{22} \mathrm{H}_{18} \mathrm{~N}_{4} \mathrm{O}_{4}$ : C, 65.66; $\mathrm{H}, 4.51$; , 13.92. Found: $\mathrm{C}, 65.41 ; \mathrm{H}, 4.88 ; \mathrm{N}, 13.65$.

5-Oxo-2-phenyl-7-(3,4,5-trimethoxyphenyl)-1,5-dihydroimidazo[1,2-a]pyrimidine-6-carbonitrile $(60)$

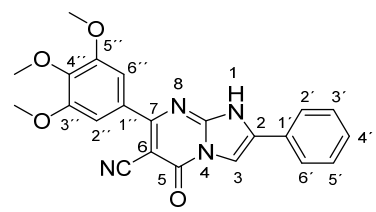

White powder; yield: $66 \%$; mp > $300{ }^{\circ} \mathrm{C} ;{ }^{1} \mathrm{H}$ NMR (400 MHz; DMSO-d6) $3.76\left(3 \mathrm{H}, \mathrm{s}, \mathrm{OCH}_{3}\right)$, 3.84 (6H, s, $\left.\mathrm{OCH}_{3}\right), 7.23$ (2H, s, H-2' ' H-6' '), 7.42-7.52 (3H, m, H-3', H-4', H-5'), 7.95 (2H, d, ${ }^{3} J=7.6 \mathrm{~Hz}, \mathrm{H}-2{ }^{\prime}, \mathrm{H}-6$ '), 8.40 ppm (1H, s, H-3); ${ }^{13} \mathrm{C}$ NMR (100 MHz; DMSO-d6) 56.04, 60.23, $82.73,104.55,106.29,117.77,125.48,127.04,129.18,129.53,131.67,131.80,139.58,146.98$, 152.53, 156.58, 165.89 ppm; Anal. Calcd for $\mathrm{C}_{22} \mathrm{H}_{18} \mathrm{~N}_{4} \mathrm{O}_{4}$ : C, 65.66; H, 4.51; N, 13.92. Found: $\mathrm{C}$, 65.34; H, 4.31; N, 13.71.

2-(4-Chlorophenyl)-5-oxo-7-(3,4,5-trimethoxyphenyl)-1,5-dihydroimidazo[1,2-a]pyrimidine-6carbonitrile (6p)

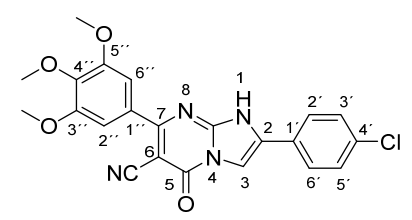

White powder; yield: 72\%; mp > $300{ }^{\circ} \mathrm{C} ;{ }^{1} \mathrm{H}$ NMR (300 MHz; DMSO-d 6$) 3.76\left(3 \mathrm{H}, \mathrm{s}, \mathrm{OCH}_{3}\right)$, 3.85 (6H, s, $\left.\mathrm{OCH}_{3}\right), 7.23$ (2H, s, H-2"', H-6"'), 7.59 (2H, d, $\left.{ }^{3} \mathrm{~J}=8.7 \mathrm{~Hz}, \mathrm{H}-2^{\prime}, \mathrm{H}-66^{\prime}\right), 7.99$ (2H, d, $\left.{ }^{3} J=8.4 \mathrm{~Hz}, \mathrm{H}-3{ }^{\prime}, \mathrm{H}-5^{\prime}\right), 8.49$ (1H, s, H-3), 14.29 ppm (1H, br., $\left.\mathrm{NH}\right) ;{ }^{13} \mathrm{C}$ NMR $(75 \mathrm{MHz}$; DMSO- $\left.d_{6}\right) 56.00,60.18,82.64,105.12$, 106.24, 117.69, 126.20, 127.18, 129.20, 130.77, 131.68, 134.01, 139.56, 146.99, 152.49, 156.53, 165.82 ppm; Anal. Calcd for $\mathrm{C}_{22} \mathrm{H}_{17} \mathrm{ClN}_{4} \mathrm{O}_{4}$ : C, 60.49; H, 3.92; N, 12.83. Found: C, 60.17; H, 3.67; N, 12.54 .

2-(4-Bromophenyl)-5-oxo-7-(3,4,5-trimethoxyphenyl)-1,5-dihydroimidazo[1,2-a]pyrimidine-6carbonitrile (6q). 


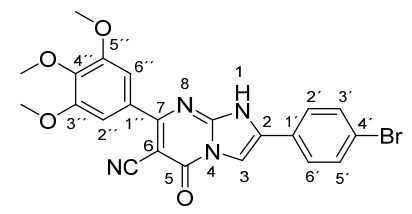

White powder; yield: 76\%; mp 295-297 ${ }^{\circ} \mathrm{C}$; $\max (\operatorname{atr}) / \mathrm{cm}^{-1} 3200,3111,2215,1660,1575$ and 1486; ${ }^{1} \mathrm{H}$ NMR (400 MHz; DMSO-d6) $3.76\left(3 \mathrm{H}, \mathrm{s}, \mathrm{OCH}_{3}\right), 3.84\left(6 \mathrm{H}, \mathrm{s}, \mathrm{OCH}_{3}\right), 7.22(2 \mathrm{H}, \mathrm{s}, \mathrm{H}-$ $\left.2^{\prime \prime}, \mathrm{H}-6^{\prime \prime}\right), 7.59$ (2H, d, $\left.{ }^{3} J=8.8 \mathrm{~Hz}, \mathrm{H}-2^{\prime}, \mathrm{H}-6^{\prime}\right), 7.99$ (2H, d, $\left.{ }^{3} \mathrm{~J}=8.8 \mathrm{~Hz}, \mathrm{H}-3^{\prime}, \mathrm{H}-5^{\prime}\right), 8.48$ ppm $(1 \mathrm{H}, \mathrm{s}, \mathrm{H}-3) ;{ }^{13} \mathrm{C}$ NMR (100 MHz; DMSO-d6) 56.01, 60.19, 82.64, 105.13, 106.25, 117.71, 126.21, 127.20, 128.96, 129.22, 131.69, 134.03, 139.57, 147.01, 152.50, 156.55, 165.40 ppm; Anal. Calcd for $\mathrm{C}_{22} \mathrm{H}_{17} \mathrm{BrN}_{4} \mathrm{O}_{4}$ : C, 54.90; H, 3.56; N, 11.64. Found: C, 54.71; H, 3.23; N, 11.35 .

5-Oxo-2-(p-tolyl)-7-(3,4,5-trimethoxyphenyl)-1,5-dihydroimidazo[1,2- $a$ ]pyrimidine-6carbonitrile (6r)

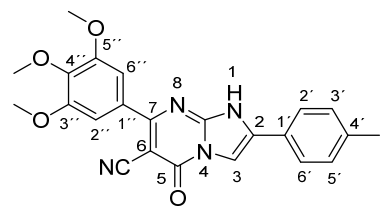

White powder; yield: $64 \%$; $\mathrm{mp}>300{ }^{\circ} \mathrm{C} ;{ }^{1} \mathrm{H}$ NMR (400 MHz; DMSO- $\left.d_{6}\right) 2.33\left(3 \mathrm{H}, \mathrm{s}, \mathrm{CH}_{3}\right), 3.75$ $\left(3 \mathrm{H}, \mathrm{s}, \mathrm{OCH}_{3}\right), 3.84\left(6 \mathrm{H}, \mathrm{s}, \mathrm{OCH}_{3}\right), 7.21\left(2 \mathrm{H}, \mathrm{s}, \mathrm{H}-2^{\prime \prime}, \mathrm{H}-6^{\prime \prime}\right), 7.46\left(2 \mathrm{H}, \mathrm{d},{ }^{3} \mathrm{~J}=8.4 \mathrm{~Hz}, \mathrm{H}-3^{\prime}, \mathrm{H}-\right.$ $\left.5^{\prime}\right), 7.92\left(2 \mathrm{H}, \mathrm{d},{ }^{3} \mathrm{~J}=8.8 \mathrm{~Hz}, \mathrm{H}-2^{\prime}, \mathrm{H}-6\right.$ ' $), 8.10 \mathrm{ppm}(1 \mathrm{H}, \mathrm{s}, \mathrm{H}-3) ;{ }^{13} \mathrm{C}$ NMR (100 MHz; DMSOd6) $20.88,55.96,60.16,95.03,103.29$, 104.22, 106.17, 118.68, 125.30, 126.88, 128.69, 129.50, 132.12, 139.12, 152.40, 157.06, 157.39, 164.24 ppm; Anal. Calcd for $\mathrm{C}_{23} \mathrm{H}_{20} \mathrm{~N}_{4} \mathrm{O}_{4}$ : C, 66.34; $\mathrm{H}$, 4.84; N, 13.45. Found: C, 66.01; H, 4.54; N, 13.12.

2-(2-Methoxyphenyl)-5-oxo-7-(3,4,5-trimethoxyphenyl)-1,5-dihydroimidazo[1,2-a]pyrimidine-6carbonitrile (6s)

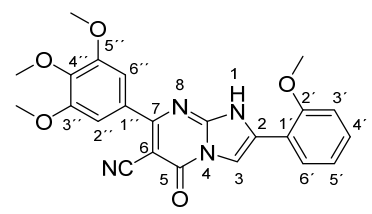

White powder; yield: $61 \%$; $\mathrm{mp}>300{ }^{\circ} \mathrm{C}$; $v$ max (atr)/cm ${ }^{-1} 3400,3120,2942,2214,1671,1594$ and 1492; ${ }^{1} \mathrm{H}$ NMR (300 MHz; DMSO-d6) $3.76\left(3 \mathrm{H}, \mathrm{s}, \mathrm{OCH}_{3}\right), 3.85\left(6 \mathrm{H}, \mathrm{s}, \mathrm{OCH}_{3}\right), 3.99(3 \mathrm{H}, \mathrm{s}$, $\left.\mathrm{OCH}_{3}\right), 7.11\left(1 \mathrm{H}, \mathrm{t},{ }^{3} J=7.2 \mathrm{~Hz}\right), 7.22-7.24(3 \mathrm{H}, \mathrm{m}), 7.46\left(1 \mathrm{H}, \mathrm{t},{ }^{3} J=7.2 \mathrm{~Hz}\right), 7.91\left(1 \mathrm{H}, \mathrm{d},{ }^{3} \mathrm{~J}=\right.$ $7.8 \mathrm{~Hz}), 8.02$ (1H, s, H-3), 14.01 ppm (1H, br., NH); ${ }^{13} \mathrm{C}$ NMR (75 MHz; DMSO-d6) 55.80, 
$56.00,60.17,82.54,106.26,106.42,111.96,115.15,117.76,120.80,127.19,130.82,131.84$, 139.50, 146.29, 152.47, 156.52, 165.94 ppm; Anal. Calcd for $\mathrm{C}_{23} \mathrm{H}_{20} \mathrm{~N}_{4} \mathrm{O}_{5}$ : C, 63.88; H, 4.66; N, 12.96. Found: C, 63.64; H, 4.92; N, 12.72.

2-(3,4-Dichlorophenyl)-5-oxo-7-(3,4,5-trimethoxyphenyl)-1,5-dihydroimidazo[1,2-a]pyrimidine6-carbonitrile (6t)

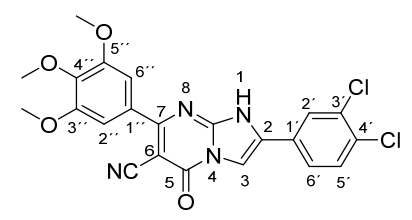

White powder; yield: 73\%; mp 198-200 ${ }^{\circ} \mathrm{C}$; $v$ max (atr)/ $\mathrm{cm}^{-1} 3300,3117,2942,2208,1661$, 1592, 1478; ${ }^{1} \mathrm{H}$ NMR (400 MHz; DMSO-d6) $3.76\left(3 \mathrm{H}, \mathrm{s}, \mathrm{OCH}_{3}\right), 3.85\left(6 \mathrm{H}, \mathrm{s}, \mathrm{OCH}_{3}\right), 7.22(2 \mathrm{H}$, s, H-2", $\left.\mathrm{H}-6^{\prime \prime}\right), 7.79\left(1 \mathrm{H}, \mathrm{d},{ }^{3} J=8.4 \mathrm{~Hz}, \mathrm{H}-5^{\prime}\right), 7.96\left(1 \mathrm{H}, \mathrm{dd},{ }^{3} J=8.4 \mathrm{~Hz},{ }^{4} \mathrm{~J}=2.1 \mathrm{~Hz}, \mathrm{H}-6^{\prime}\right)$, $8.30\left(1 \mathrm{H}, \mathrm{d},{ }^{4} \mathrm{~J}=1.8 \mathrm{~Hz}, \mathrm{H}-2^{\prime}\right), 8.60 \mathrm{ppm}(1 \mathrm{H}, \mathrm{s}, \mathrm{H}-3) ;{ }^{13} \mathrm{C}$ NMR (100 MHz; DMSO-d6) 56.02, $60.20,82.65,106.14,106.27,117.64,125.43,127.22,129.89,131.35,131.76,132.12,134.34$, 139.63, 146.99, 152.51, 156.52, 161.97, 165.71 ppm; Anal. Calcd for $\mathrm{C}_{22} \mathrm{H}_{16} \mathrm{Cl}_{2} \mathrm{~N}_{4} \mathrm{O}_{4}$ : C, 56.07; H, 3.42; N, 11.89. Found: C, 56.33; H, 3.76; N, 11.60 .

2-(Naphthalen-2-yl)-5-oxo-7-(3,4,5-trimethoxyphenyl)-1,5-dihydroimidazo[1,2-a]pyrimidine-6carbonitrile (6u)

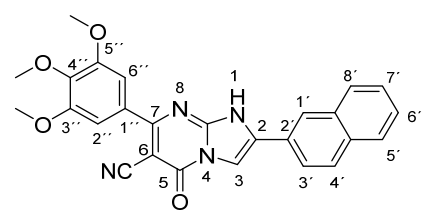

White powder; yield: $60 \%$; mp > $300{ }^{\circ} \mathrm{C}$; ${ }^{1} \mathrm{H}$ NMR (400 MHz; DMSO- $\left.d_{6}\right) 3.77\left(3 \mathrm{H}, \mathrm{s}, \mathrm{OCH}_{3}\right)$, $3.86\left(6 \mathrm{H}, \mathrm{s}, \mathrm{OCH}_{3}\right), 7.25$ (2H, s, H-2"', H-6"'), 7.56-7.60 (2H, m), 7.91-7.99 (3H, m), 8.11-8.12 $(1 \mathrm{H}, \mathrm{m}), 8.54$ (1H, s, H-3 or H-1'), 8.55 (1H, s, H-3 or H-1'), 14.38 ppm (1H, br., NH); Anal. Calcd for $\mathrm{C}_{26} \mathrm{H}_{20} \mathrm{~N}_{4} \mathrm{O}_{4}$ : C, 69.02; H, 4.46; N, 12.38. Found: C, 69.38; H, 4.65; N, 12.05.

2-(4-Chlorophenyl)-7-methylimidazo[1,2-a]pyrimidin-5(1H)-one (9a) 


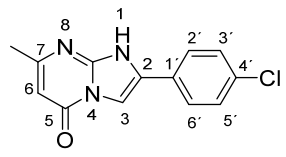

White powder; yield: $48 \%$; $\mathrm{mp}>300{ }^{\circ} \mathrm{C}$; $v$ max (atr)/ $\mathrm{cm}^{-1} 3310,2960,1675,1563$ and $1479 ;{ }^{1} \mathrm{H}$ NMR (400 MHz; DMSO-d6) 2.29 (3H, s, CH $), 5.47$ (1H, s, H-6), $7.42\left(2 \mathrm{H}, \mathrm{d},{ }^{3} J=8.4 \mathrm{~Hz}, \mathrm{H}-2^{\prime}\right.$, H-6'), $7.90\left(2 \mathrm{H}, \mathrm{d},{ }^{3} \mathrm{~J}=8.4 \mathrm{~Hz}, \mathrm{H}-3^{\prime}, \mathrm{H}-5^{\prime}\right), 7.97 \mathrm{ppm}(1 \mathrm{H}, \mathrm{s}, \mathrm{H}-3) ;{ }^{13} \mathrm{C}$ NMR (100 MHz; DMSO- $\left.d_{6}\right) 21.14,93.43,103.06,126.75,128.52,131.50,132.69,137.97,147.15,155.17,157.60$ ppm; Anal. Calcd for $\mathrm{C}_{13} \mathrm{H}_{10} \mathrm{ClN}_{3} \mathrm{O}$ : C, 60.13; H, 3.88; N, 16.18. Found: C, 60.37; H, 3.98; N, 16.40 .

7-Ethyl-2-(4-fluorophenyl)imidazo[1,2-a]pyrimidin-5(1H)-one (9b)

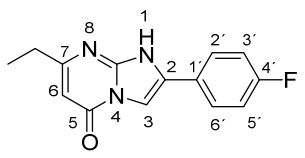

White powder; yield: $48 \%$; mp $>300{ }^{\circ} \mathrm{C}$; ${ }^{1} \mathrm{H}$ NMR (400 MHz; DMSO- $\left.d_{6}\right) 1.22\left(3 \mathrm{H}, \mathrm{t},{ }^{3} J=7.2\right.$ $\left.\mathrm{Hz}, \mathrm{CH}_{3}\right), 2.57\left(2 \mathrm{H}, \mathrm{q},{ }^{3} \mathrm{~J}=7.2 \mathrm{~Hz}, \mathrm{CH}_{2}\right), 5.65(1 \mathrm{H}, \mathrm{s}, \mathrm{H}-6), 7.25\left(2 \mathrm{H}, \mathrm{t},{ }^{3} \mathrm{~J}=8.8 \mathrm{~Hz}, \mathrm{H}-3^{\prime}, \mathrm{H}-5^{\prime}\right)$, 7.92-7.96 (2H, m, H-2', H-6' $), 8.10$ ppm (1H, s, H-3); Anal. Calcd for $\mathrm{C}_{14} \mathrm{H}_{12} \mathrm{FN} 3 \mathrm{O}$ : C, 65.36; H, 4.70; N, 16.33. Found: C, 65.61; H, 4.52; N, 16.61.

2-(4-Chlorophenyl)-7-ethylimidazo[1,2-a]pyrimidin-5(1H)-one (9c)

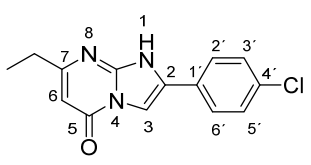

White powder; yield: $36 \%$; $\mathrm{mp}>300{ }^{\circ} \mathrm{C}$; $v$ max (atr)/ $\mathrm{cm}^{-1} 3426,3120,2928,1686,1600,1566$ and 1443; ${ }^{1} \mathrm{H}$ NMR (400 MHz; DMSO- $\left.d_{6}\right) 1.21\left(3 \mathrm{H}, \mathrm{t},{ }^{3} J=7.6 \mathrm{~Hz}, \mathrm{CH}_{3}\right), 2.57\left(2 \mathrm{H}, \mathrm{q},{ }^{3} J=7.6\right.$ $\left.\mathrm{Hz}, \mathrm{CH}_{2}\right), 5.65$ (1H, s, H-6), $7.46\left(2 \mathrm{H}, \mathrm{d},{ }^{3} J=8.4 \mathrm{~Hz}, \mathrm{H}-2^{\prime}, \mathrm{H}-6{ }^{\prime}\right), 7.91\left(2 \mathrm{H}, \mathrm{d},{ }^{3} J=8.8 \mathrm{~Hz}, \mathrm{H}-3^{\prime}\right.$, H-5'), 8.10 ppm (1H, s, H-3); ${ }^{13} \mathrm{C}$ NMR (100 MHz; DMSO-d6) 12.72, 39.96, 93.75, 104.16, $126.91,128.75,129.21,130.18,130.65,156.59,157.34,168.67$ ppm; Anal. Calcd for $\mathrm{C}_{14} \mathrm{H}_{12} \mathrm{ClN}_{3} \mathrm{O}$ : C, 61.43; H, 4.42; N, 15.35. Found: C, 61.74; H, 4.71; N, 15.00.

2-(4-Fluorophenyl)-7-phenylimidazo[1,2-a]pyrimidin-5(1H)-one (9d) 


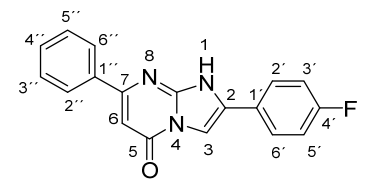

White powder; yield: $33 \%$; mp > $300{ }^{\circ} \mathrm{C} ;{ }^{1} \mathrm{H}$ NMR (400 MHz; DMSO-d6) $5.88(1 \mathrm{H}, \mathrm{s}, \mathrm{H}-6)$, 7.32-7.36 (3H, m, H-3"', H-4"', H-5'), 7.62 (2H, dd, J=8.4 Hz, J= 5.2 Hz, H-3', H-5'), 7.497.50 (2H, m, H-2"', H-6"'), 8.16 (2H, dd, $J=8.4$ Hz, $J=5.2$ Hz, H-2', H-6'), 8.21 (1H, s, H-3), 13.40 ppm $(1 \mathrm{H}$, br., $\mathrm{NH})$; Anal. Calcd for $\mathrm{C}_{18} \mathrm{H}_{12} \mathrm{FN}_{3} \mathrm{O}$ : C, 70.81; H, 3.96; N, 13.76. Found: $\mathrm{C}$, $70.58 ; \mathrm{H}, 3.65 ; \mathrm{N}, 13.43$.

\section{X-ray crystallographic study}

Crystals were grown following the protocol developed by Hope by dissolving the compound in $\mathrm{CH}_{2} \mathrm{Cl}_{2}$ and layering with a $\mathrm{MeOH}$ for liquid [41]. Single crystal X-ray diffraction data for all compounds were collected on a Bruker APEX 2 DUO CCD diffractometer by using graphitemonochromated Mo $\mathrm{K}_{\alpha}(\lambda=0.71073 \AA)$ radiation. Crystals were mounted on a MiTeGen MicroMount and collected at 100(2) K by using an Oxford Cryosystems Cobra low-temperature device. Data were collected by using omega and phi scans and were corrected for Lorentz and polarization effects by using the APEX software suite [42-44]. Using Olex2, the structure was solved with the XT structure solution program, using the intrinsic phasing solution method and refined against $\mid$ F2 $\mid$ with XL using least-squares minimization [45,46]. Hydrogen atoms were generally placed in geometrically calculated positions and refined using a riding model. The phenyl ring at $\mathrm{C} 7$ was modelled over two positions in a 50:50\% occupancy using the restraint SADI. The methoxy group at C16 were modelled over two positions in a 50:50\% occupancy using the constraint EADP. Further details of data collection and refinement can be found in Table 1 and 2 in the supporting information. All images were prepared by using Olex2 [45]. CCDC 1951700 contain the supplementary crystallographic data for this paper. These data can be obtained free of charge from The Cambridge Crystallographic Data Centre via www.ccdc.cam.ac.uk/structures.

\subsection{Biological evaluation}


Antimicrobial activity and minimum inhibitory concentration (MIC) of the synthesized compounds and positive control (Ampicillin and Levofloxacin) were evaluated by well diffusion method [31, 32].

\section{Materials and methods}

\section{Tested microbes}

The Gram (+) bacterial strains S. aureus (ATTCC 6538), and B. subtilis (ATCC 663) were used for the experiment. While E. coli (ATTCC 8739), P. aeruginosa (ATCC 9027), K. pneumonia (ATCC 10131) and S. typhi (ATCC 14028), and were selected as Gram (-) bacterial strains for this study.

\section{Preparation of inoculums}

Bacterial inoculums were prepared by growing bacteria in nutrient broth (Sigma) for $24 \mathrm{~h}$ at 37 ${ }^{\circ} \mathrm{C}$. These cell suspensions were diluted with sterile nutrient broth to provide initial cell counts of about $10^{4} \mathrm{CFU} / \mathrm{mL}$.

\section{Preparation of synthetic compounds}

A stock solution of $10 \mathrm{mg} / \mathrm{mL}$ in dimethyl sulfoxide (DMSO) of each compound was prepared.

\section{Determination of the antibacterial activity}

The well diffusion assay was used to determine and screen the antimicrobial activity of all compounds ${ }^{[31,32]}$. Petri dishes containing $20 \mathrm{~mL}$ nutrient agar culture medium at $50-70{ }^{\circ} \mathrm{C}$ was left to solidify under ultraviolet (UV) light (265 nm wavelength) for $15 \mathrm{~min}$ then they were inoculated with $0.2 \mathrm{~mL}$ of an overnight bacterial cell suspension matching a 0.5 McFarland standard solution. The suspension was uniformly spread using a sterile swab over the surface of the medium. Wells of $8 \mathrm{~mm}$ in diameter were made in the agar plates with a sterile glass Pasteur pipette and $0.1 \mathrm{~mL}$ of each compound of the stock solution was added into the wells. DMSO was used as a negative control while ampicillin and levofloxacin $(10 \mathrm{mg} / \mathrm{mL})$ were used as positive controls. The plates were then incubated at $37^{\circ} \mathrm{C}$ for $24 \mathrm{~h}$. The antimicrobial activity was assayed by measuring the diameters of the inhibition zone formed around the wells in mm. Each assay was performed at least in triplicate. 


\section{Determination of the minimal inhibitory concentration}

Minimum inhibitory concentration studies of isolated compounds were performed according to the standard reference method for bacteria $[31,32]$. The Petri dishes were inoculated with the strains as described before using the microdilution method $[31,32]$. The tested compounds and the positive control (Ampicillin and levofloxacin) were diluted at different concentrations ranging from 10 to $0.05 \mathrm{mg} / \mathrm{mL}$ and each concentration was placed in a separate well. The Petri dishes were incubated for $24 \mathrm{~h}$ at $37{ }^{\circ} \mathrm{C}$. The MIC was defined as the lowest concentration of the compound capable of preventing the microbial growth in the culture medium.

\section{Gyrase ATPase assay}

This assay is based on the transformation of phosphoenolpyruvate (PEP) to pyruvate kinase (PK) consequent with the conversion of pyruvate to lactate by lactate dehydrogenase (LDH) in presence of NADH which is oxidized to NAD+. NADH absorbs strongly at $340 \mathrm{nM}$ but NAD+ does not, enabling the reduction of NADH over time to be followed by monitoring the decrease in absorbance at $340 \mathrm{nM}$. E. coli Gyrase for ATPase Assay kit (inspiralis) was used for testing the synthesized imidazopyrimidines $\mathbf{6 c}, \mathbf{6 d}, \mathbf{6 f}, \mathbf{6 g}$ and 9d. Assays were carried out according to the manufacturer's procedure in clear colorless 96-well flat bottomed plates with a final volume of $100 \mu \mathrm{l}$ of the established assay buffer (50 mM Tris- $\mathrm{HCl}$ (pH 7.5), $1 \mathrm{mM} \mathrm{EDTA,} 5 \mathrm{mM} \mathrm{MgCl} 2,5$ $\mathrm{mM}$ DTT, $10 \%$ (wt/vol) glycerol) containing $1 \mathrm{U}(10 \mu \mathrm{l}$ of $500 \mathrm{nM})$ of gyrase, $800 \mu \mathrm{M}$ phosphoenolpyruvate, $400 \mu \mathrm{M}$ NADH, $1.5 \mu$ phosphokinase/lactate dehydrogenase (PK/LDH) enzyme mix (Sigma P0294), DNA and different concentrations of inhibitors. The mix was then

incubated for 10 mins at $25^{\circ} \mathrm{C}$. Reactions are then initiated by the addition of $2 \mathrm{mM}$ ATP and the decrease in absorbance at $340 \mathrm{~nm}$ was measured over time using an BioTek ${ }^{\circledR}$ Synergy HT fluorescence plate reader. IC 50 values were calculated using GraphPad Prism software.

\section{Acknowledgments}

The authors are grateful for the National Cancer Institute (NCI), Bethesda, Maryland, USA for performing the anticancer screening for the selected compounds over their panel of cell lines. Deep thanks to Bioorganische Chemie, Institut für Chemie, Universität Hohenheim for running some NMR spectra. The X-ray analysis and most of the NMR measurements were supported by a grant from Science Foundation Ireland (SFI IvP 13/IA/1894). 


\section{Conflict of interest}

The authors have no conflict of interest to declare.

\section{References}

[1] M. S. Morehead, C. Scarbrough, Prim Care 2018, 45, 467-484.

[2] C. Llor, L. Bjerrum, Ther Adv Drug Saf 2014, 5, 229-241.

[3] R. J. Fair, Y. Tor, Perspect Medicin Chem 2014, 6, 25-64.

[4] R. J. Reece, A. Maxwell, Crit Rev Biochem Mol Biol 1991, 26, 335-375.

[5] F. Collin, S. Karkare, A. Maxwell, Appl Microbiol Biotechnol 2011, 92, 479-497.

[6] T. Khan, K. Sankhe, V. Suvarna, A. Sherje, K. Patel, B. Dravyakar, Biomed Pharmacother 2018, 103, 923-938.

[7] M. Oblak, M. Kotnik, T. Solmajer, Curr Med Chem 2007, 14, 2033-2047.

[8] M. Trzoss, D. C. Bensen, X. Li, Z. Chen, T. Lam, J. Zhang, C. J. Creighton, M. L. Cunningham, B. Kwan, M. Stidham, K. Nelson, V. Brown-Driver, A. Castellano, K. J. Shaw, F. C. Lightstone, S. E. Wong, T. B. Nguyen, J. Finn, L. W. Tari, Bioorg Med Chem Lett 2013, 23, 1537-1543.

[9] L. W. Tari, M. Trzoss, D. C. Bensen, X. Li, Z. Chen, T. Lam, J. Zhang, C. J. Creighton, M. L. Cunningham, B. Kwan, M. Stidham, K. J. Shaw, F. C. Lightstone, S. E. Wong, T. B. Nguyen, J. Nix, J. Finn, Bioorg Med Chem Lett 2013, 23, 1529-1536.

[10] J. T. Starr, R. J. Sciotti, D. L. Hanna, M. D. Huband, L. M. Mullins, H. Cai, J. W. Gage, M. Lockard, M. R. Rauckhorst, R. M. Owen, M. S. Lall, M. Tomilo, H. Chen, S. P. McCurdy, M. R. Barbachyn, Bioorg Med Chem Lett 2009, 19, 5302-5306.

[11] P. S. Charifson, A. L. Grillot, T. H. Grossman, J. D. Parsons, M. Badia, S. Bellon, D. D. Deininger, J. E. Drumm, C. H. Gross, A. LeTiran, Y. Liao, N. Mani, D. P. Nicolau, E. Perola, S. Ronkin, D. Shannon, L. L. Swenson, Q. Tang, P. R. Tessier, S. K. Tian, M. Trudeau, T. Wang, Y. Wei, H. Zhang, D. Stamos, J Med Chem 2008, 51, 5243-5263.

[12] T. Germe, J. Voros, F. Jeannot, T. Taillier, R. A. Stavenger, E. Bacque, A. Maxwell, B. D. Bax, Nucleic Acids Res 2018, 46, 4114-4128.

[13] M. Gjorgjieva, T. Tomasic, M. Barancokova, S. Katsamakas, J. Ilas, P. Tammela, L. Peterlin Masic, D. Kikelj, J Med Chem 2016, 59, 8941-8954.

[14] A. Tanitame, Y. Oyamada, K. Ofuji, Y. Kyoya, K. Suzuki, H. Ito, M. Kawasaki, K. Nagai, M. Wachi, J. Yamagishi, Bioorg Med Chem Lett 2004, 14, 2857-2862. 
[15] M. Brvar, A. Perdih, M. Renko, G. Anderluh, D. Turk, T. Solmajer, J Med Chem 2012, $55,6413-6426$.

[16] M. Uria-Nickelsen, G. Neckermann, S. Sriram, B. Andrews, J. I. Manchester, D. Carcanague, S. Stokes, K. G. Hull, Int J Antimicrob Agents 2013, 41, 363-371.

[17] R. O'Shea, H. E. Moser, J Med Chem 2008, 51, 2871-2878.

[18] C. Global Burden of Disease Cancer, C. Fitzmaurice, C. Allen, R. M. Barber, L. Barregard, Z. A. Bhutta, H. Brenner, D. J. Dicker, O. Chimed-Orchir, R. Dandona, L. Dandona, T. Fleming, M. H. Forouzanfar, J. Hancock, R. J. Hay, R. Hunter-Merrill, C. Huynh, H. D. Hosgood, C. O. Johnson, J. B. Jonas, J. Khubchandani, G. A. Kumar, M. Kutz, Q. Lan, H. J. Larson, X. Liang, S. S. Lim, A. D. Lopez, M. F. MacIntyre, L. Marczak, N. Marquez, A. H. Mokdad, C. Pinho, F. Pourmalek, J. A. Salomon, J. R. Sanabria, L. Sandar, B. Sartorius, S. M. Schwartz, K. A. Shackelford, K. Shibuya, J. Stanaway, C. Steiner, J. Sun, K. Takahashi, S. E. Vollset, T. Vos, J. A. Wagner, H. Wang, R. Westerman, H. Zeeb, L. Zoeckler, F. Abd-Allah, M. B. Ahmed, S. Alabed, N. K. Alam, S. F. Aldhahri, G. Alem, M. A. Alemayohu, R. Ali, R. Al-Raddadi, A. Amare, Y. Amoako, A. Artaman, H. Asayesh, N. Atnafu, A. Awasthi, H. B. Saleem, A. Barac, N. Bedi, I. Bensenor, A. Berhane, E. Bernabé, B. Betsu, A. Binagwaho, D. Boneya, I. Campos-Nonato, C. Castañeda-Orjuela, F. Catalá-López, P. Chiang, C. Chibueze, A. Chitheer, J.-Y. Choi, B. Cowie, S. Damtew, J. das Neves, S. Dey, S. Dharmaratne, P. Dhillon, E. Ding, T. Driscoll, D. Ekwueme, A. Y. Endries, M. Farvid, F. Farzadfar, J. Fernandes, F. Fischer, T. T. G/hiwot, A. Gebru, S. Gopalani, et al., JAMA Oncology 2017, 3,524 .

[19] K. O. Alfarouk, C. M. Stock, S. Taylor, M. Walsh, A. K. Muddathir, D. Verduzco, A. H. Bashir, O. Y. Mohammed, G. O. Elhassan, S. Harguindey, S. J. Reshkin, M. E. Ibrahim, C. Rauch, Cancer Cell Int 2015, 15, 71.

[20] H. T. Abdel-Mohsen, F. A. Ragab, M. M. Ramla, H. I. El Diwani, Eur J Med Chem 2010, $45,2336-2344$.

[21] H. T. Abdel-Mohsen, J. Conrad, K. Harms, D. Nohr, U. Beifuss, RSC Advances 2017, 7, 17427-17441.

[22] H. T. Abdel-Mohsen, J. Conrad, U. Beifuss, J Org Chem 2013, 78, 7986-8003.

[23] H. T. Abdel-Mohsen, A. S. Girgis, A. E. E. Mahmoud, M. M. Ali, H. I. El Diwani, Arch Pharm (Weinheim) 2019, e1900089. 
[24] H. T. Abdel-Mohsen, M. A. Omar, A. M. El Kerdawy, A. E. E. Mahmoud, M. M. Ali, H. I. El Diwani, Eur J Med Chem 2019, 179, 707-722.

[25] M. Sahu, N. Siddiqui, International Journal of Pharmacy and Pharmaceutical Sciences 2016, 8-21.

[26] T. H. Al-Tel, R. A. Al-Qawasmeh, Eur J Med Chem 2010, 45, 5848-5855.

[27] A. Kamal, G. Bharath Kumar, V. Lakshma Nayak, V. S. Reddy, A. B. Shaik, R. Rajender, M. Kashi Reddy, MedChemComm 2015, 6, 606-612.

[28] H. I. El Diwani, H. T. Abdel-Mohsen, I. Salama, F. A.-F. Ragab, M. M. Ramla, S. A. Galal, M. M. Abdalla, A. Abdel-Wahab, M. A. El Demellawy, Chemical and Pharmaceutical Bulletin 2014, 62, 856-866.

[29] M. A. Abdullaziz, H. T. Abdel-Mohsen, A. M. El Kerdawy, F. A. F. Ragab, M. M. Ali, S. M. Abu-Bakr, A. S. Girgis, H. I. El Diwani, Eur J Med Chem 2017, 136, 315-329.

[30] R. Goel, V. Luxami, K. Paul, RSC Advances 2015, 5, 81608-81637.

[31] N. R. Bhalodia, V. J. Shukla, J Adv Pharm Technol Res 2011, 2, 104-109.

[32] M. A. Shakhatreh, M. L. Al-Smadi, O. F. Khabour, F. A. Shuaibu, E. I. Hussein, K. H. Alzoubi, Drug Des Devel Ther 2016, 10, 3653-3660.

[33] A. Daina, O. Michielin, V. Zoete, Sci Rep 2017, 7, 42717.

[34] A. Daina, O. Michielin, V. Zoete, J Chem Inf Model 2014, 54, 3284-3301.

[35] C. A. Lipinski, F. Lombardo, B. W. Dominy, P. J. Feeney, Adv Drug Deliv Rev 2001, 46, $3-26$.

[36] D. F. Veber, S. R. Johnson, H. Y. Cheng, B. R. Smith, K. W. Ward, K. D. Kopple, J Med Chem 2002, 45, 2615-2623.

[37] A. K. Ghose, V. N. Viswanadhan, J. J. Wendoloski, J Comb Chem 1999, 1, 55-68.

[38] W. J. Egan, K. M. Merz, Jr., J. J. Baldwin, J Med Chem 2000, 43, 3867-3877.

[39] I. Muegge, S. L. Heald, D. Brittelli, J Med Chem 2001, 44, 1841-1846.

[40] J. B. Baell, G. A. Holloway, J Med Chem 2010, 53, 2719-2740.

[41] H. Hope, in Progress in Inorganic Chemistry (Ed.: K. D. Karlin), John Wiley \& Sons, Inc., Hoboken, NJ, USA, 2007, pp. 1-19.

[42] Saint, Version 8.37a; Bruker AXS, Inc.: Madison, WI, 2013.

[43] SADABS, version 2016/2, Bruker AXS, Inc.: Madison, WI, 2014.

[44] APEX3, Version 2016.9-0, Bruker AXS, Inc.: Madison, WI, 2016. 
[45] O. V. Dolomanov, L. J. Bourhis, R. J. Gildea, J. A. K. Howard, H. Puschmann, J. Appl. Crystallogr. 2009, 42, 339-341.

[46] G. Sheldrick, Acta Cryst. Sect. A 2015, 71, 3-8. 